\title{
Degradation of pharmaceuticals from wastewater in a 20-L continuous flow bio-electro-
} Fenton (BEF) system

\author{
Zou, Rusen; Angelidaki, Irini; Yang, Xiaoyong; Tang, Kai; Andersen, Henrik Rasmus; Zhang, Yifeng
}

Published in:

Science of the Total Environment

Link to article, DOI:

10.1016/j.scitotenv.2020.138684

Publication date:

2020

Document Version

Peer reviewed version

Link back to DTU Orbit

Citation (APA):

Zou, R., Angelidaki, I., Yang, X., Tang, K., Andersen, H. R., \& Zhang, Y. (2020). Degradation of pharmaceuticals from wastewater in a 20-L continuous flow bio-electro-Fenton (BEF) system. Science of the Total Environment, 727, [138684]. https://doi.org/10.1016/j.scitotenv.2020.138684

\section{General rights}

Copyright and moral rights for the publications made accessible in the public portal are retained by the authors and/or other copyright owners and it is a condition of accessing publications that users recognise and abide by the legal requirements associated with these rights.

- Users may download and print one copy of any publication from the public portal for the purpose of private study or research.

- You may not further distribute the material or use it for any profit-making activity or commercial gain

- You may freely distribute the URL identifying the publication in the public portal 


\section{Journal Pre-proof}

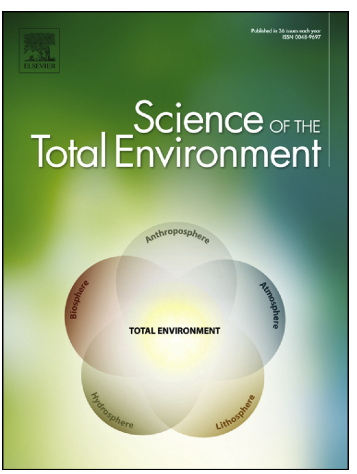

Rusen Zou, Irini Angelidaki, Xiaoyong Yang, Kai Tang, Henrik Rasmus Andersen, Yifeng Zhang

Degradation of pharmaceuticals from wastewater in a $20-\mathrm{L}$ continuous flow bio-electro-Fenton (BEF) system

PII: $\quad$ S0048-9697(20)32201-4

DOI: $\quad$ https://doi.org/10.1016/j.scitotenv.2020.138684

Reference: $\quad$ STOTEN 138684

To appear in: $\quad$ Science of the Total Environment

Received date: $\quad 20$ February 2020

Revised date: $\quad 9$ April 2020

Accepted date: $\quad 11$ April 2020

Please cite this article as: R. Zou, I. Angelidaki, X. Yang, et al., Degradation of pharmaceuticals from wastewater in a 20 -L continuous flow bio-electro-Fenton (BEF) system, Science of the Total Environment (2020), https://doi.org/10.1016/ j.scitotenv.2020.138684

This is a PDF file of an article that has undergone enhancements after acceptance, such as the addition of a cover page and metadata, and formatting for readability, but it is not yet the definitive version of record. This version will undergo additional copyediting, typesetting and review before it is published in its final form, but we are providing this version to give early visibility of the article. Please note that, during the production process, errors may be discovered which could affect the content, and all legal disclaimers that apply to the journal pertain.

(C) 2020 Published by Elsevier. 
Degradation of pharmaceuticals from wastewater in a 20 - $\mathrm{L}$ continuous flow bio-electroFenton (BEF) system

Rusen Zou, Irini Angelidaki, Xiaoyong Yang, Kai Tang, Henrik Rasmus Andersen, Yifeng Zhang*

Department of Environmental Engineering, Technical University of Denmark, DK-2800 Lyngby,

Denmark

*Corresponding author:

Dr. Yifeng Zhang

Department of Environmental Engineering, Technical University of Denmark, Denmark

Tel: (+45) 45251410

Fax: (+45) 45933850

E-mail address: yifz@env.dtu.dk; yifzmfc@gmail.com 


\section{Abstract}

The bio-electro-Fenton (BEF) technology has proven to be an effective and energy-saving method for treating wastewaters containing a single pharmaceutical in the lab-scale. However, the continuous degradation of pharmaceuticals in a scaled-up BEF has never been reported. In this study, a 20-L dual-chamber BEF reactor was designed and tested for treating six model pharmaceuticals. The effect of key operational factors including applied voltage, cathode $\mathrm{Fe}^{2+}$ dosage, initial pharmaceuticals concentration and hydraulic retention time (HRT), were assessed. By implementing $0.1 \mathrm{~V}$ voltage, $0.3 \mathrm{mM} \mathrm{Fe}^{2+}$ and HRT of $26 \mathrm{~h}$, the six selected pharmaceuticals (500 $\mu \mathrm{g} \mathrm{L}^{-1}$ for each) were removed completely. Moreover, transformation products during clofibric acid degradation, such as 4-chlororesorcinol, were detected and the relevant transformation pathway was proposed. Additionally, it successfully removed these pharmaceuticals in the real wastewater matrix. This paper contributes to scaling-up the BEF process for continuous and effective treating pharmaceuticals-contaminated wastewater.

Keywords: Bio-electro-Fenton; Scaling-up; Pharmaceuticals; Wastewater treatment; Transformation pathway 


\section{Introduction}

Over the last few decades, a strong and growing demand for pharmaceuticals has occurred as a result of global population growth and advances in medicine. Although the use of various pharmaceuticals, such as antibiotics, antipyretics, analgesics, non-steroidal anti-inflammatory drugs (NSAIDs), antimicrobials, etc., can bring many benefits such as saving and extending lives, ameliorating suffering and improving quality of life, large amounts of wastewater containing pharmaceuticals have been discharged into the environment with an average treatment ratio (wastewater treatment plant, WWTP) of less than 30\% (Hu et al., 2018). Previous studies on environmental hazard assessments have suggested that many pharmaceuticals are environmentally hazardous to aquatic organisms and might pose long-term negative risks to humans (Vandenberg et al., 2012; Wilkinson et al., 2016). Consequently, discharge such inefficiently treated pharmaceuticals-containing effluent by conventional WWTP has turned into a serious contribution to water pollution. However, due to improved analytical chemistry techniques, it is possible to detect compounds at a trace-level concentration (i.e. $\mathrm{ng}^{-1}$ ) in natural aquatic environments (Bouissou-Schurtz et al., 2014; Kümmerer, 2001). Since the human health and environmental risks of these pharmaceuticals are high, extensive research efforts have been devoted to finding effective ways to remove them from wastewater. In general, existing removal methods can be classified into three groups, namely physical adsorption, chemical advanced oxidation, and biological degradation. Among the existing treatment technologies, electro-Fenton (EF), which combines traditional chemical Fenton's oxidation with electrochemistry, has a number of unique merits, including high removal efficiency, mild operating conditions and the ability to complete pharmaceutical mineralization (Brillas et al., 2009; Plakas et al., 2016; Sirés et al., 2007). However, the major challenges involved in high electric energy consumption, scaling-up and costly electrodes hinder the widespread application of the technology ( $\mathrm{Li}$ et al., 2017d; Monteil et al., 2018; Zhou et al., 2017) 
More recently, an innovative process, entailing the integration of conventional EF and namely bioelectro-Fenton (BEF), which offers the ability of strong oxidation by EF and the low energy consumption of microbial electrochemical systems biodegradation, has been developed to reduce electrical energy consumption (Feng et al., 2010; Olvera-Vargas et al., 2016; Zhu \& Ni, 2009). Compared with the traditional EF technology, much lower electricity input $(0.2-0.8 \mathrm{~V})$ is required in the BEF process, due to in-situ electricity generation by anode electroactive bacteria through decomposing of organic matter (e.g. wastewater) and generate electrons, protons, and carbon dioxide. In the cathode chamber, the major electrode reactions can be explained as follows. Firstly, $\mathrm{H}_{2} \mathrm{O}_{2}$ is in-situ generated via a two-electron oxygen reduction reaction (ORR) (Eq. (1)). Secondly, hydroxyl radicals $(\cdot \mathrm{OH})$ is formed by the reaction between $\mathrm{H}_{2} \mathrm{O}_{2}$ and $\mathrm{Fe}^{2+}$ (Eq. (2)). Thirdly, the regeneration occurs via $\mathrm{Fe}^{3+}$ reduction (Eq. (3)).

$\mathrm{O}_{2}+2 \mathrm{H}^{+}+2 \mathrm{e}^{-} \rightarrow \mathrm{H}_{2} \mathrm{O}_{2}(1)$

$\mathrm{H}_{2} \mathrm{O}_{2}+\mathrm{Fe}^{2+}+\mathrm{H}^{+} \rightarrow \cdot \mathrm{OH}+\mathrm{Fe}^{3+}+\mathrm{H}_{2} \mathrm{O}(2)$

$\mathrm{Fe}^{3+}+\mathrm{e}^{-} \rightarrow \mathrm{Fe}^{2+}(3)$

BEF process has been developed for treating pollutants in diverse wastewaters, like dyes (Li et al., 2017c; Zhang et al., 2015b), pharmaceuticals (Nadais et al., 2018; Wang et al., 2018; Zhang et al., 2015a) and municipal, agricultural and industrial pollutants (Hassan et al., 2017; Yong et al., 2017; Yu et al., 2018). Though promising, most studies have been carried out in labs, with reactor sizes in the hundreds of milliliters and the scaling-up feasibility of these systems has never been explored. Furthermore, previous BEF process studies focused mainly on wastewater containing a single pharmaceutical, while the continuous degradation of pharmaceuticals in wastewater has never been reported, let alone in terms of a 20 -L system.

Thus, the core purpose of current work is to develop a 20-L BEF reactor for the continuous treatment of pharmaceutical wastewater containing NSAIDs (diclofenac, ibuprofen, ketoprofen, and naproxen), an anticonvulsant (carbamazepine) and a lipid regulator (clorfibric acid), all of which 
have been detected in varying concentrations in urban effluent (Gurke et al., 2015; Laurencé et al., 2014; Papageorgiou et al., 2016). The previous studies regarding pharmaceuticals removal by labscale BEF process are shown in Table 1 . Therefore, the feasibility of the 20 -L BEF process for pharmaceutical containing wastewater treatment was first evaluated. The effects of operational parameters, including initial pharmaceuticals concentration, $\mathrm{Fe}^{2+}$ dosage, applied voltage as well as hydraulic retention time (HRT), on system performance were explored. Finally, the transformation products and the corresponding transformation pathway of clorfibric acid were determined. This research provides insights into developing a large-scale BEF system for future commercial applications such as the tertiary treatment facility of traditional WWTP to effectively remove pharmaceuticals.

\section{Materials and methods}

\subsection{BEF system setup and operation}

A rectangular, two-chamber BEF reactor $(20 \mathrm{~cm} \times 20 \mathrm{~cm} \times 25 \mathrm{~cm}$ for each chamber $)$ was set up for the experiments (Fig.1). The cathode and anode chambers of the BEF reactor were separated by a cation exchange membrane (CEM, CMI 7001, Membrane International, NJ), which can let the $\mathrm{H}^{+}$ produced in anode be transported to the cathode as well as prevent the aerated air diffused to the anode. Stainless steel screws and silicone gaskets were used to avoid leakage whilst assembling this 20-L BEF reactor. The total and working volumes of each chamber of the BEF reactor were $10 \mathrm{~L}$ and 9 L, respectively. There were 20 electrodes in each chamber, arranged as exhibited in Fig.1. The carbon brush (diameter $5.9 \mathrm{~cm}$, length $6.9 \mathrm{~cm}$, Mill-Rose, USA) was used as the anode, which was pretreated before use as previously described. (Zhang \& Angelidaki, 2015). The working electrodes and reference electrode in the cathode chamber of the BEF reactor were commercial graphite plates (projected size of each was $4.5 \mathrm{~cm} \times 4.5 \mathrm{~cm})$ and $\mathrm{Ag} / \mathrm{AgCl}$ electrode $(+0.197 \mathrm{~V}$ vs SHE, Pine Instrument Company, USA), respectively. 
The BEF system was first operated as a microbial fuel cell and was fed with domestic wastewater containing $1 \mathrm{~g} \mathrm{~L}^{-1}$ of sodium acetate (Lyngby Wastewater Treatment Plant, Denmark) to cultivate mature anodic biofilms. Domestic wastewater was used as inoculum and sodium acetate was used as carbon source. After one month of operation, when the current output was stable, the BEF system was running as a microbial electrolysis cell, and the anaerobic anode chamber was continuously fed with synthetic nutrient medium. The detailed ingredients of the synthetic nutrient medium are as described in the previous study (Kvesitadze et al., 2012). The HRT of the solution in the anode chamber was set to $58 \mathrm{~h}$, to maintain anode performance (Zhang et al., 2015b). Synthetic wastewater laden with diclofenac, ibuprofen, ketoprofen, carbamazepine, clofibric acid and naproxen, each at different concentrations $\left(250,500\right.$ and $\left.1000 \mu \mathrm{g} \mathrm{L}^{-1}\right)$, was used to investigate the effect of initial pharmaceutical concentration on the system performance. The abiotic cathode chamber was fed with $\mathrm{Na}_{2} \mathrm{SO}_{4}(50 \mathrm{mM})$ solution unless stated otherwise. $\mathrm{FeSO}_{4} \cdot 7 \mathrm{H}_{2} \mathrm{O}$, as an iron catalyst, was also added into the synthetic pharmaceutical wastewater. The catholyte $\mathrm{pH}$ was adjusted by using $\mathrm{H}_{2} \mathrm{SO}_{4}$ solution ( $3 \mathrm{M}$ ). The catholyte remained in a continuous flow, and the catholyte $\mathrm{pH}$ was maintained at 2.8 . The cathodic aeration rate was set to $350 \mathrm{~mL} \mathrm{~min}^{-1}$ by using a peristaltic pump (OLE DITCH, Instrument Makers APS, Denmark), corresponding to an equilibrium dissolved oxygen (DO) concentration of about $7.8 \mathrm{mg} \mathrm{L}^{-1}$ at $28{ }^{\circ} \mathrm{C}$, unless stated otherwise. Moreover, different HRTs were also set to test system performance when the catholyte was in continuous flow. For the trials with real wastewater, effluents after secondary biological treatment (Lyngby Wastewater Treatment Plant, Copenhagen, Denmark) with TOC of $25.48 \mathrm{mg} \mathrm{L}^{-1}$ were taken. When the system was operating in BEF mode, a $0.1 \Omega$ external resistance was connected between anode and cathode. A constant voltage of $0.1 \mathrm{~V}$ was supplied by using a potentiostat (CT-4008W, Neware Battery Testing System, China), except for investigating the effect of different voltages $(0.05$ and $0.2 \mathrm{~V})$. Control experiment conditions were conducted for an open circuit (Control 1), without cathode aeration (Control 2) or no $\mathrm{Fe}^{2+}$ addition (Control 3). The 
stirring speed of both anolyte and catholyte was set to $200 \mathrm{rpm}$. All experiments were performed in duplicate at room temperature $\left(20 \pm 2{ }^{\circ} \mathrm{C}\right)$.

\subsection{Chemicals}

A stock solution $\left(1 \mathrm{~g} \mathrm{~L}^{-1}\right)$ was prepared by weighing $0.1 \mathrm{~g}$ each of the six selected pharmaceuticals (clofibric acid, diclofenac, carbamazepine, naproxen, ibuprofen, and ketoprofen) and dissolving the mixture in $10 \mathrm{~mL}$ of methanol (Merck Darmstadt, Germany), and analytical-grade substances in this regard were purchased from Sigma-Aldrich, Denmark.

\subsection{Analytical Methods}

The $\mathrm{pH}$ value of the treated effluent was determined by a $\mathrm{pH}$ meter (PHM $210 \mathrm{pH}$ meter, Radiometer). The potentiostat recorded current and cathode potential every $10 \mathrm{~min}$. The power consumption induced by the pumping and stirring were recorded by a sparOmeter electricity meter (Type NZR230, S.L. Energitekinik, Denmark).

A total of $10 \mathrm{~mL}$ of each sample was collected from the cathode chamber at given time intervals, 6 $\mathrm{mL}$ of which was used to test immediately the $\mathrm{pH}$ and any remaining $\mathrm{H}_{2} \mathrm{O}_{2}$ concentrations. Then, the concentration of $\mathrm{H}_{2} \mathrm{O}_{2}$ was determined as described in the previous study (Nadais et al., 2018). Samples collected for pharmaceuticals concentration and transformation products of clofibric acid analysis were kept at $-20{ }^{\circ} \mathrm{C}$ before analysis. Gas chromatography/mass spectrometry (GC/MS, Agilent GC 6890 N, MSD 5973 N utilizing a CombipAL from CTC analytics as auto-sampler) was used to quantify the concentration of pharmaceutical compounds. The detailed derivatization procedure, chromatography and MS conditions were carried out as previously described (Hey et al., 2012; Nadais et al., 2018). Furthermore, a high-performance liquid chromatography (Agilent 1290 Infinity, USA, HPLC) system with a tandem mass spectrometer (Agilent 6470 series, USA, MS/MS) was used in the experiment set up to identify the degradation of clofibric acid by-products. Detailed operating parameters are described as following: the HPLC system consisted of a pump, a column oven, a degasser, and an auto-sampler all supplied from Agilent 1290 Infinity, USA. 
Chromatographic separation was performed using a C18 column $(2.1$ x $50 \mathrm{~mm}, 1.8 \mu \mathrm{m}$, Eclipse Agilent, USA). The temperature of the HPLC column oven was $35^{\circ} \mathrm{C}$, and the constant flow rate was $0.6 \mathrm{~mL} \mathrm{~min}{ }^{-1}$. The HPLC gradient was formed by changing the mix ratio of Milli-Q water including $0.1 \%$ ammonium formate (solvent A) and 90\% acetonitrile/10\% Milli-Q water including $0.1 \%$ ammonium formate (solvent B). A mass spectrometer equipped with the triple quadrupole was from Agilent 6470 series, USA. The gradient was initiated with $0 \% \mathrm{~B}$, followed by a linear increase of gradient B up to $100 \%$ within $20 \mathrm{~min}$. Initial gradient conditions were also reestablished for 3 mins. An MS 2 scan, starting from $60 \mathrm{Da}$ to $350 \mathrm{Da}$ in the ESI-ionisation mode, was introduced to identify the clofibric acid by-product. The sheath gas flow was $12 \mathrm{~L} \mathrm{~min}^{-1}$ at a temperature of $400{ }^{\circ} \mathrm{C}$, while the gas flow was $10 \mathrm{~L} \mathrm{~min}^{-1}$ at a temperature of $260{ }^{\circ} \mathrm{C}$. The injection volume was $10 \mu \mathrm{L}$. In addition, the apparent rate constants for removing six selected pharmaceuticals under different operating parameters were determined based on a previous study (Li et al., 2017a; Li et al., 2017c; Nadais et al., 2018).

\section{Results and discussion}

\subsection{Pharmaceuticals elimination in batch mode}

As shown in Fig. 2, the six selected pharmaceuticals as a mixture can be completely removed within $18 \mathrm{~h}$ with a $0.2 \mathrm{~V}$ voltage supply. The increase of removal rate was positively correlated with the applied voltage ranging from 0.05 to $0.2 \mathrm{~V}$. Correspondingly, system current increased as the applied voltage increased, which can be seen in Fig. S1. The above results match up with the findings in previous studies in terms that applied voltage can affect the current in the BEF process and thereby further control the generation of $\mathrm{H}_{2} \mathrm{O}_{2}$ and its induced $\cdot \mathrm{OH}$ ( $\mathrm{Li}$ et al., 2017a; $\mathrm{Li}$ et al., 2017c; Nadais et al., 2018). Comparatively, in an open circuit condition (Control 1), only $2.6 \%$ of clofibric acid, $2 \%$ of diclofenac, $3.8 \%$ of carbamazepine, $1.4 \%$ of naproxen, $2.6 \%$ of ibuprofen and $1.8 \%$ of ketoprofen were removed. This phenomenon could be explained by the occurrence of sorption between pharmaceuticals and CEM as well as cathode electrodes. Similarly, 
pharmaceutical removal efficiencies in those systems without any airflow in the cathode (Control 2), or without $\mathrm{Fe}^{2+}$ addition (Control 3), were lower than 26\%. Also, the concentration of $\mathrm{H}_{2} \mathrm{O}_{2}$ progressively raised and achieved $120 \mathrm{mg} \mathrm{L}^{-1}$ at $18 \mathrm{~h}$ in the system without $\mathrm{Fe}^{2+}$ addition, while no $\mathrm{H}_{2} \mathrm{O}_{2}$ was detected under other conditions (Fig. S1). In line with the observed results, we could draw some basic conclusions as following. First, sorption by CEM and electrode, or $\mathrm{H}_{2} \mathrm{O}_{2}$ alone and without $\mathrm{Fe}^{2+}$, cannot effectively remove six selected pharmaceuticals. Second, electricity-driven $\mathrm{H}_{2} \mathrm{O}_{2}$ synthesis followed by a Fenton reaction induced by $\mathrm{Fe}^{2+}$ was the main reason for pharmaceutical degradation. Furthermore, based on data from the batch experiment, only a small variation was observed in $\mathrm{pH}$ (from 3 to 3.4) with different applied voltages (Fig. S1), which was in the optimum $\mathrm{EF}$ and $\mathrm{BEF}$ process reaction ranges reported by the previous literature (Laurencé et al., 2014; Sellers, 1980; Zhang et al., 2012). In conclusion, the results demonstrate the feasibility of this novel 20-L BEF process for pharmaceutical-containing wastewater treatment.

\subsection{Pharmaceuticals elimination in continuous flow mode with implementations of operational}

\section{parameters}

It is advantageous for industrial applications that the reactor operates in continuous mode. However, most previous studies are carried in batch mode, so testing this scaling-up BEF system for continuous pharmaceuticals removal is important to validate the feasibility of this technology under industrial-scale conditions. In this section, the effects of applied voltage, $\mathrm{FeSO}_{4}$ dosage, different HRTs and initial pharmaceutical concentration on removal efficiency are investigated. Other operational parameters, such as initial $\mathrm{pH}$, supporting electrolytes as well as air supply, are set based on the optimal operation conditions obtained directly from previous research (Li et al., 2017a; Monteil et al., 2018; Nadais et al., 2018).

\subsubsection{Effect of different applied voltages}

It has been documented that the in-situ generation of $\mathrm{H}_{2} \mathrm{O}_{2}$ and further conversion to $\cdot \mathrm{OH}$, can be controlled through circuit current density (Estrada et al., 2012; Li et al., 2017a; Nadais et al., 2018). 
Hence, applied voltages with $0.05 \mathrm{~V}, 0.1 \mathrm{~V}$, and $0.2 \mathrm{~V}$ were used to study their effects on pharmaceutical removal. During the tests, $500 \mu \mathrm{g} \mathrm{L}^{-1}$ of each pharmaceutical, initial $\mathrm{pH}$ of $2.8, \mathrm{Fe}^{2+}$ of $1 \mathrm{mM}, \mathrm{Na}_{2} \mathrm{SO}_{4}$ of $50 \mathrm{mM}$, air flow rate of $350 \mathrm{~mL} \mathrm{~min}^{-1}$ and $\mathrm{HRT}$ of $23 \mathrm{~h}$ in the cathode was chosen, based on batch experiments. The removal rates for diclofenac, clofibric acid and carbamazepine (see in Fig. 3) increased from nearly $80 \%$ to $100 \%$ along with increasing applied voltage from 0.05 to $0.1 \mathrm{~V}$ over $69 \mathrm{~h}$ operation (with HRT of $23 \mathrm{~h}$ ). There was no apparent observation on the improvement of pharmaceutical removal when $0.2 \mathrm{~V}$ of voltage was applied. For ketoprofen and ibuprofen, removal rates reached $100 \%$ with an applied voltage of $0.05 \mathrm{~V}$, but when it further increased to $0.1 \mathrm{~V}$ or even $0.2 \mathrm{~V}$, the reaction rate of ketoprofen was enhanced significantly. As for naproxen, by increasing the applied voltage from 0.05 to $0.2 \mathrm{~V}$, where the removal rate raised slightly from $87 \%$ to $92 \%$. In general, the pharmaceuticals removal rate increased with the increase of the applied voltage. This was due to the increase in electro- $\mathrm{H}_{2} \mathrm{O}_{2}$ production, which subsequently lead to more $\cdot \mathrm{OH}$ generation. Additionally, it was found that the removal of those pharmaceuticals in the BEF process with tested applied voltage conformed to pseudo-first-order kinetics, and the kinetics constants were showed in Table S1. The rate constant of each pharmaceutical increased first as the applied voltage raised from 0.05 to $0.1 \mathrm{~V}$. But further increasing to $0.2 \mathrm{~V}$, it began to decline (diclofenac, clofibric acid and carbamazepine). It was worth noting that the rate constant of ibuprofen was much larger than the others, probably because ibuprofen was easily removed through the BEF process. Similar results were also obtained that the rate constant rate of ibuprofen was higher than naproxen and ketoprofen in an $80 \mathrm{~mL}$ lab-scale $\mathrm{BEF}$ process (Nadais et al., 2018). Moreover, Zhao et al explored the removal of ibuprofen and naproxen in a photoelectrochemical process and observed the faster removal rate of ibuprofen due to the complex molecular structure of naproxen (Zhao et al., 2009). Effluent pH (as seen in Fig. S2) showed a slight increase from 2.8 to 3.4 while the applied voltage was changed from 0.05 to $0.2 \mathrm{~V}$ after three HRTs. 
The above results indicate that any further control of cathodic $\mathrm{pH}$ was not necessary for continuous flow mode when an influent $\mathrm{pH}$ of 2.8 was applied in the cathode. The current increased in line with increasing the applied voltage (Fig. S2), which was consistent with changes in treatment performance. While an increase in applied voltage can improve treatment performance, it may in turn increase energy consumption, so the applied voltage of $0.1 \mathrm{~V}$ was selected for subsequent experiments.

\subsubsection{Effect of different initial pharmaceutical concentrations}

The previous research has shown that the performance of pollutant removal by the BEF process was independent of the pollutant concentration ( $\mathrm{Li}$ et al., 2017a). Therefore, the influence on the removal of the six selected pharmaceuticals in continuous flow mode was studied further at three different initial concentrations $\left(250,500\right.$ and $\left.1000 \mu \mathrm{g} \mathrm{L}^{-1}\right)$. The other fixed operational parameters were as following: initial $\mathrm{pH}$ of $2.8, \mathrm{Fe}^{2+}$ of $1 \mathrm{mM}, \mathrm{Na}_{2} \mathrm{SO}_{4}$ of $50 \mathrm{mM}$, air flow rate of $350 \mathrm{~mL} \min ^{-1}$ and HRT of 23 h. The results presented in Fig. 4 show that pharmaceutical concentrations dropped rapidly in the first $8 \mathrm{~h}$, following which removal rate stabilized after approx. $24 \mathrm{~h}$. For clofibric acid, diclofenac, carbamazepine, ibuprofen and ketoprofen with initial concentrations of 250 and $500 \mu \mathrm{g}$ $\mathrm{L}^{-1}$, approximatively $100 \%$ of their removal rates were observed after $48 \mathrm{~h}$, while removal rates ranged from $72 \%$ to $85 \%$ at $1000 \mu \mathrm{g} \mathrm{L}^{-1}$, except for ibuprofen (100\%). As for naproxen, the degradation efficiencies stabilized after around $24 \mathrm{~h}$ at $100 \%, 90 \%$ and $88 \%$ with initial concentrations of 250, 500 and $1000 \mu \mathrm{g} \mathrm{L} \mathrm{L}^{-1}$, respectively. A similar result, that is, a higher concentration corresponds to a lower removal efficiency, was also found in our group's previous research on the degradation of the orange $G$ by the BEF process with different initial orange $G$ concentrations. This phenomenon can be explained as the constant number of $\cdot \mathrm{OH}$ produced under the given operating condition while the concentrations of pharmaceuticals molecules were increased (Kahoush et al., 2018). Similarly, the removal of those pharmaceuticals in the BEF process with tested initial concentration also followed pseudo-first-order kinetics, and the rate constants can be 
seen in Table. S2. It can be found in Table S2 that the rate constants of pharmaceuticals (diclofenac, clofibric acid and naproxen) firstly increased as the concentration of the initial pharmaceutical increased from 250 to $500 \mu \mathrm{g} \mathrm{L}^{-1}$. This may be related to increasing the number of pharmaceuticals molecules participated in the Fenton reaction, which caused $\cdot \mathrm{OH}$ more involved in the desired reaction and thus increased pharmaceuticals removal rate (Kahoush et al., 2018). Thereafter, the rate constant of each pharmaceutical decreased when initial concentration further increased to 1000 $\mu \mathrm{g} \mathrm{L}^{-1}$. Similar tendencies have been observed in EF and BEF processes treating dyes (Li et al., 2017c; Zhang et al., 2015b) and pharmaceuticals (Labiadh et al., 2015; Liu et al., 2018). To overcome this saturation issue, and to improve removal efficiencies at higher initial concentrations, it may be necessary to initiate a relatively longer treatment time or a higher applied voltage. Labscale BEFs were generally applied to low-concentration pollutants at a range of $\mu \mathrm{g} \mathrm{L}^{-1}$ (Nadais et al., 2018; Wang et al., 2017). The results obtained with this 20-L BEF system indicate that BEF technology could also be used for high-strength pharmaceutical wastewater treatment, implying good viability for industrial applications.

\subsubsection{Effect of different HRTs}

HRT is an important parameter affecting treatment efficiency and capacity (Plakas et al., 2016; Zhang et al., 2012). Thus, the 20-L BEF process was tested under three HRTs (16, 23 and $26 \mathrm{~h})$, with other fixed operational parameters (an initial pharmaceutical concentration of $500 \mu \mathrm{g} \mathrm{L}^{-1}, \mathrm{pH}$ of $2.8, \mathrm{Na}_{2} \mathrm{SO}_{4}$ of $50 \mathrm{mM}$, applied voltage of $0.1 \mathrm{~V}$, airflow rate of $350 \mathrm{~mL} \mathrm{~min}^{-1}$ and $\mathrm{Fe}^{2+}$ of $1 \mathrm{mM}$ ). Fig. 5 showed the corresponding degradation efficiency of the six selected pharmaceuticals. There was a clear relationship between HRT and degradation efficiency. The higher degradation efficiency was obtained when the longer HRT was set. The pharmaceuticals (except ibuprofen which reached $100 \%$ removal at HRT of $16 \mathrm{~h}$ ) removal rates ranged from $80 \%$ to $85 \%$ when HRT was $16 \mathrm{~h}$. The previous study on using moving bed biofilm reactor (MBBR) technology for the removal of six selected pharmaceuticals also obtained the highest removal efficiency of ibuprofen 
(94\%), followed by diclofenac (85\%), naproxen (80\%), ketoprofen (63\%), clofibric acid (5\%), and carbamazepine (0\%) (Zupanc et al., 2013). When extending HRT to $23 \mathrm{~h}, 100 \%$ removal of carbamazepine, clofibric acid, ketoprofen, diclofenac and ibuprofen, and 90\% removal of naproxen were observed. Finally, all the pharmaceuticals can be completely removed at HRT of $26 \mathrm{~h}$. These results suggest by adjusting the HRT of the BEF reactor, it is possible to achieve adequate removal of pharmaceuticals. The reason can be that there was sufficient reaction time between the generated $\cdot \mathrm{OH}$ and pharmaceuticals, and thus more $\cdot \mathrm{OH}$ was involved in the degradation of pharmaceuticals with the extension of HRT. It is notable that the selected pharmaceuticals were treated without operational problems and can be entirely removed without the addition of other oxidant agents like $\mathrm{H}_{2} \mathrm{O}_{2}$ and $\mathrm{O}_{3}$. The results indicate the suitability of this system to treat pharmaceuticals-containing wastewater. Based on the removal rates, HRT of $26 \mathrm{~h}$ was chosen for the following experiments.

\subsubsection{Effect of different initial catholyte $\mathrm{Fe}^{2+}$ concentration}

It has been reported widely in EF and BEF process literature that one of the key prerequisites is the dosing of $\mathrm{Fe}^{2+}$, which is not harmful and can significantly affect the oxidation of organic pollutants, as it can react with $\mathrm{H}_{2} \mathrm{O}_{2}$ to produce $\cdot \mathrm{OH}$ radicals (Brillas et al., 2009; Nadais et al., 2018).

The influence of initial $\mathrm{Fe}^{2+}$ dosage $(0.3,0.5,1.0,2.0$ and $4 \mathrm{mM})$ on pharmaceuticals degradation was investigated with a set of defined parameters (initial pharmaceutical concentration of $500 \mu \mathrm{g} \mathrm{L}^{-}$ 1, $\mathrm{pH}$ of $2.8, \mathrm{Na}_{2} \mathrm{SO}_{4}$ of $50 \mathrm{mM}$, applied voltage of $0.1 \mathrm{~V}, \mathrm{HRT}$ of $26 \mathrm{~h}$ and air flow rate of $350 \mathrm{~mL}$ $\min ^{-1}$ ). The initial concentration of $\mathrm{Fe}^{2+}$ did have an obvious influence on the pharmaceutical removal (see in Fig. 6) because when it was between 0.3 and $0.5 \mathrm{mM}$, the rapid and complete removal of all six selected pharmaceuticals was observed. However, the removal efficiency and rate of the six selected pharmaceuticals decreased by increasing $\mathrm{Fe}^{2+}$ concentrations further (to 1,2 and $4 \mathrm{mM}$ ). For example, removal rate for clofibric acid, diclofenac, carbamazepine, naproxen, and ketoprofen was around $70 \%$ on average at an initial $\mathrm{Fe}^{2+}$ concentration of $4 \mathrm{mM}$, while an average 
removal rate of $80 \%$ was achieved at an initial $2 \mathrm{mM}$ dose of $\mathrm{Fe}^{2+}$. The $\mathrm{Fe}^{2+}$ concentration was able to positively affect the organic pollutant degradation performance by $\mathrm{EF}$ and $\mathrm{BEF}$ process below a certain range, and by increasing $\mathrm{Fe}^{2+}$ concentration further, the degradation rate may start to decrease caused by a competitive reaction between excess $\mathrm{Fe}^{2+}$ and $\cdot \mathrm{OH}$, and eventually formed $\mathrm{Fe}^{3+}$. (Eq. (6)).

$\mathrm{Fe}^{2+}+\cdot \mathrm{OH} \rightarrow \mathrm{Fe}^{3+}+\mathrm{OH}^{-}$

In addition, a side reaction occurred (Eq. (7)) because excessive $\mathrm{Fe}^{2+}$ added could produce numerous $\cdot \mathrm{OH}$ instantaneously (Eq. (2)), which could then further promote the consumption of $\cdot \mathrm{OH}$ and $\mathrm{H}_{2} \mathrm{O}_{2}$.

$\cdot \mathrm{OH}+\mathrm{H}_{2} \mathrm{O}_{2} \rightarrow \cdot \mathrm{HO}_{2}+\mathrm{H}_{2} \mathrm{O}(7)$

These reactions consumed $\cdot \mathrm{OH}$ and $\mathrm{H}_{2} \mathrm{O}_{2}$ and resulted in the poor performance of pharmaceutical degradation (Monteil et al., 2019).

Since there were no significant differences in pharmaceutical degradation between initial $\mathrm{Fe}^{2+}$ dosages at 0.3 and $0.5 \mathrm{mM}, 0.3 \mathrm{mM}$ could be chosen for future applications. It has been reported that the optimum $\mathrm{Fe}^{2+}$ concentration for the EF process is in the range of 0.1-0.5 mM (Monteil et al., 2018; Oturan \& Aaron, 2014; Sirés et al., 2014), and so the result was consistent with traditional EF process. Furthermore, compared with other lab-scale systems, the $\mathrm{Fe}^{2+}$ concentration required by this 20-L BEF reactor was lower (Li et al., 2017c; Nadais et al., 2018; Zhang et al., 2015b). Overall, the results imply that the $20-\mathrm{L}$ BEF process could maintain the same or even lower levels of $\mathrm{Fe}^{2+}$ consumption.

\subsubsection{Energy consumption}

Energy consumption is the most expensive part of any EF process. Comparatively, BEF oxidation technology has been proven to be a more energy-efficient way to approach recalcitrant wastewater treatment (Li et al., 2017a; Li et al., 2017c; Nadais et al., 2018). In this 20-L BEF reactor, energy consumption was mainly included in two ways: electricity consumption for providing the applied 
voltage, and electricity consumption for stirring and aeration. The first part can be calculated according to Eq. (8):

$E=\frac{I \times V \times t}{V s}$

where $\mathrm{E}\left(\mathrm{kWh} \mathrm{m}^{-3}\right)$ represents power consumption regarding the applied voltage, $\mathrm{I}$ is the current intensity (A), V is the applied voltage (V), $\mathrm{t}$ is the HRT (h) and Vs is the working volume of the cathode (L). Hence, electricity consumption for the first part after one HRT based on the selected operating parameters (applied voltage of $0.1 \mathrm{~V}, \mathrm{Fe}^{2+}$ concentration of $0.3 \mathrm{mM}$ and HRT of $26 \mathrm{~h}$ ), was $8.67 \times 10^{-3} \mathrm{kWh} \mathrm{m}^{-3}$.

Energy consumption for the second part was $0.44 \mathrm{kWh}$ after one HRT, equating to $48.889 \mathrm{kWh} \mathrm{m}^{-3}$. Therefore, the final total figure was $48.89 \mathrm{kWh} \mathrm{m}^{-3}$, which means that energy consumption in terms of the 20-L BEF reactor mainly contributed by aeration with a ratio of $99.98 \%$. Our previous studies provided information about reactor cost and electricity price, which were approximately 930 $€ \mathrm{~m}^{-3}$ and $0.13 € \mathrm{kWh}^{-1}$, respectively (Li et al., 2017b; Nadais et al., 2018). Accordingly, the operating cost for treating $1 \mathrm{~m}^{3}$ of such pharmaceuticals containing wastewater was $5.84 €$. To the best of our knowledge, most previous works have focused only on energy consumption for the first part. For example, in a previous study, using an $80 \mathrm{~mL}$ lab-scale BEF reactor for NSAIDscontaining wastewater treatment, energy consumption for applied voltage was $29.875 \mathrm{kWh} \mathrm{m}^{-3}$ (Nadais et al., 2018). Besides, it should be mentioned that the concentration of treated pollutants which was of $40 \mu \mathrm{g} \mathrm{L}^{-1}$ of each four NSAIDs for the lab-scale reactor against $500 \mu \mathrm{g} \mathrm{L}^{-1}$ of each six selected pharmaceuticals including that four NSAIDs for our 20-L reactor. Therefore, assuming the treatment of the same amount of pollutants as the continuous operation, the operation cost of $80 \mathrm{~mL}$ lab-scale BEF process in batch mode was as high as $71.25 €$. Besides the reactor volume and/or the concentration of the pharmaceuticals, the difference in electricity consumption could be the electrolyte and the type and the effective size of the electrode. Greater effort should there be expended to optimize cathode aeration further and to reduce total energy consumption, thus 
reducing overall treatment costs. In addition, some renewable energy sources such as wind energy and solar energy can be used to drive the reactor in the future to further reduce energy consumption. In general terms, the 20-L BEF process could become a competitive and energy-saving technology applied to wastewater treatment when it contains pharmaceuticals.

\subsection{The pharmaceuticals transformation pathway in BEF system}

Understanding the transformation pathway and intermediate products of pollutants is important, in order to evaluate the treatment process better, especially in a 20-L BEF system. Among the six selected pharmaceuticals, clofibric acid has attracted widespread attention because it was difficult to be degraded by traditional biological treatments and can persist in the aquatic environment. For example, it has been found that the removal rate of clofibric acid by traditional WWTP was only $55 \%$, while the half-life of photolytic clofibric acid in the natural environment can be as long as 250 days in winter ( $\mathrm{Li}$ et al., 2010). Thus, clofibric acid was selected as an example, and its transformation pathway in the 20-L BEF process was investigated by using the HPLC-MS/MS under MS2 scan. As can be seen from the obtained total ion chromatogram (Fig. S3), two main peaks of the suspected were observed at retention times of 2.73 and $10.85 \mathrm{~min}$, respectively. Furthermore, the mass spectrum of each of the two peaks was studied and exhibited in Fig. S4. Since clofibric acid was analyzed in negative ionization mode $\left([\mathrm{M}-\mathrm{H}]^{+}\right)$, five main products with molecular ion peaks of $\mathrm{m} / \mathrm{z} 112.9$ (2.73 $\mathrm{min}), 144.8(2.73 \mathrm{~min}), 188.9(2.73 \mathrm{~min}), 248.8(10.85 \mathrm{~min})$ and 265.0 (10.85 $\mathrm{min}$ ) have been found, respectively. Peaks of $\mathrm{m} / \mathrm{z} 112.9,144.8$ and 265.0 were individually elucidated as chlorobenzene, 4-chlorocatechol and 2-(4-chlorophenoxy)-2methylpropanoic acid compound with methanol and hydrogen peroxide (1:1:1), respectively. Among of which, except for 4-chlorocatechol, the rest of transformation products above mentioned have also been observed in previous studies regarding the removal of clofibric acid by UV/chlorine disinfection, photocatalytic, EF and photo EF processes (Chen et al., 2017; Sirés et al., 2007; Tang et al., 2018). 
Based on the MS/MS analysis and previous studies (Chen et al., 2017; Sirés et al., 2007; Tang et al., 2018), two transformation pathways of clofibric acid in the 20-L BEF process were then proposed (Fig. 7). As described by frontier orbital theory, the C-position of clofibric acid with higher values of $\mathrm{FED}_{\text {Hомо }}^{2}+\mathrm{FED}_{\text {LUMо }}^{2}$ can be attacked easier by $\cdot \mathrm{OH}$, where $\mathrm{FED}_{\text {Hомо represents frontier }}$ electron densities (FED) of the highest occupied molecular orbital (HOMO) and FED $_{\text {LUMO }}$ represents FEDs of the lowest occupied molecular orbital (LUMO) (Chen et al., 2017; Wahab et al., 2009). The previous study has demonstrated that the C-positions of clofibric acid, including the C1, $\mathrm{C} 2, \mathrm{C} 5, \mathrm{C} 6$ and $\mathrm{C} 7$ sites (shown in Fig.7), have higher $\mathrm{FED}^{2}{ }_{\text {Hомо }}+\mathrm{FED}^{2}$ Lumo values (Chen et al. 2017). Both pathways incited an electrophilic adduct reaction by $\cdot \mathrm{OH}$, following which multihydroxylation intermediate products formed. In pathway 1, the $\mathrm{C} 1$ and $\mathrm{C} 7$ sites were attacked simultaneously by $\cdot \mathrm{OH}$ and formed $\mathrm{P} 1(\mathrm{~m} / \mathrm{z} 248.8)$, which was then attacked by $\cdot \mathrm{OH}$ via demethylation and decarboxylation processes, thereby forming $\mathrm{P} 2$ (m/z 188.9). In addition, the stable byproduct of 4-chlorocatechol (m/z 144.8) formed after further demethylation and decarboxylation processes (Wahab et al., 2009). Ultimately, the 4-chlorocatechol could be oxidized to form small-molecule chlorobenzene ( $\mathrm{m} / \mathrm{z}$ 112.9). 4-chlorocatechol and chlorobenzene were also detected in removing clofibric acid during EF, photo EF and photocatalytic processes (Chen et al., 2017; Sirés et al., 2007). Further verification was performed by comparing mass spectra and retention time of samples to the standard purchased from Sigma-Aldrich (Munich, Germany). The results indicated that the suspected transformation products with the retention time $(2.73 \mathrm{~min})$ and mass spectra $(\mathrm{m} / \mathrm{z}=144.8)$ was confirmed to be 4-chlorocatechol, as a transformation product during clofibric acid degradation in the 20-L BEF process (see SI Fig. S3 for details).

In pathway 2 , the $\mathrm{C} 2$ site was attacked by $\cdot \mathrm{OH}$ and formed $\mathrm{P} 3(\mathrm{~m} / \mathrm{z} 265)$. Previous studies have demonstrated that the initial generation of mono-hydroxylation product 2-(4-chloro-3-hydroxyphenoxy)-2-methyl-propionic acid can be achieved by $\cdot \mathrm{OH}$ attacks at the $\mathrm{C} 2$ site forms initially, which was also detected in current work (Chen et al., 2017; Zhang et al., 2018). Thereafter, the P3 
was formed during further oxidation. In summary, these intermediate products were oxidized further by $\cdot \mathrm{OH}$ to form the smaller molecule products and finally mineralized into $\mathrm{CO}_{2}$ and $\mathrm{H}_{2} \mathrm{O}$.

\subsection{Applied to real wastewater}

In fact, the discharge of treated effluent from WWTP was the main route for micropollutants to enter the aquatic environment (Luo et al., 2014). Thus, the applicability of the 20-L BEF process for removing the pharmaceuticals in real wastewater after secondary biological treatment was evaluated. The detail characteristics of wastewater can be seen in Table S3. The operation parameters settings were based on the integration of the optimized settings in section 3.2. In addition, applied voltage $(0.1$ and $0.2 \mathrm{~V})$ and HRT (26 and $36 \mathrm{~h}$ ) were varied during the test to observe the corresponding changes in the pharmaceuticals removal rate. As shown in Fig. 8, 37-90\% of six selected pharmaceuticals were removed in real wastewater matrix at the applied voltage of $0.1 \mathrm{~V}$ and HRT of $26 \mathrm{~h}$, which were relatively lower than that achieved removal rates from the laboratory water distribution (100\% removal) under the same condition. The reason can be summarized as the following. Firstly, natural organic matters $(\mathrm{NOM})$ in real wastewater may consume the generated $\cdot \mathrm{OH}$ and resulted in a lower removal rate (Nadais et al., 2018). Secondly, the real wastewater had lower ionic strength compared to the synthetic wastewater, which resulted in relatively lower current (Fig. S6) and caused a drop in $\cdot \mathrm{OH}$ production and eventually affected treatment efficiency (Moreira et al., 2017; Nadais et al., 2018; Thiam et al., 2015) Thirdly, the inhibition effect of inorganic ions such as phosphate (Table S3) in real wastewater could also lower the treatment efficiency. The previous study has found that the formation of $\mathrm{Fe}^{3+}$-phosphate complexes led to the reduction in micropollutants removal efficiency during Fenton processes (Antonin et al., 2015; Nadais et al., 2018; Wang et al., 2016).

Considering the low treatment performance observed at $0.1 \mathrm{~V}$, raise the applied voltage further to $0.2 \mathrm{~V}$ and exhibited an obviously improved removal rate of six selected pharmaceuticals over two HRTs (Fig. 8). The removal rate of clofibric acid, diclofenac carbamazepine, naproxen, ibuprofen 
and ketoprofen increased from $44 \%, 66 \%, 37 \%, 89 \%, 85 \%$ and $58 \%$ to $78 \%, 87 \%, 76 \%, 96 \%, 92 \%$ and $86 \%$, respectively. The variation in effluent $\mathrm{pH}$ showed the same trend as using synthetic wastewater (Fig. S6), which increased slightly from 2.8 to 3.4 when increasing the applied voltage from 0.1 to $0.2 \mathrm{~V}$ after two HRTs. The reason can be attributed to the increase in current with a relatively higher-high voltage which enhanced the $\cdot \mathrm{OH}$ production and improved the removal rate. Furthermore, the removal rate of six selected pharmaceuticals was improved by further extending HRT to 36 h. As also exhibited in Fig. 8, the removal rate of the six selected pharmaceuticals first increased from 78 to $94 \mathrm{~h}$ and then significantly decreased in the remaining $20 \mathrm{~h}$. This phenomenon could be due to the rapid rise of cathodic $\mathrm{pH} . \mathrm{pH}$ in the effluent (as seen in Fig. S6) presented a slight increase (3.4 to 4.0 ) from 78 to $94 \mathrm{~h}$ and then rapidly increased from 4.0 to 6.3 in the remaining $20 \mathrm{~h}$. Previous studies found that optimum $\mathrm{pH}$ was ranging from 2.0 to 4.0 for $\mathrm{EF}$ and BEF oxidation processes (Fan et al., 2010; Flox et al., 2006; Nadais et al., 2018). Therefore, the reasons for the reduction in removal efficiency obtained after $94 \mathrm{~h}$ can be summarized into the following: 1) the rapid rise of $\mathrm{pH}$ caused the precipitation of iron; 2) carbonate and bicarbonate can exist when $\mathrm{pH}$ was above 5 , which can further eliminate $\cdot \mathrm{OH} ; 3$ ) the generated $\mathrm{H}_{2} \mathrm{O}_{2}$ could decompose to $\mathrm{O}_{2}$ and $\mathrm{H}_{2} \mathrm{O}$ automatically when $\mathrm{pH}$ was above 5 (Moreira et al., 2017). Therefore, the removal rate can be increased by further controlling $\mathrm{pH}$ in the cathode chamber. In addition, the TOC removal rate was only $35 \%$ at $0.1 \mathrm{~V}$, while it increased to $64 \%$ at $0.2 \mathrm{~V}$ after two HRTs (Fig. S6). When the HRT was extended to $36 \mathrm{~h}$, the TOC removal rate in the first $16 \mathrm{~h}$ was $82 \%$ and then decreased to $52 \%$ in the remaining $20 \mathrm{~h}$. The above results demonstrate the potential of the $20-\mathrm{L}$ BEF process for practical application in real wastewater treatment.

Overall, the $\mathrm{pH}$ adjustment and low conductivity in real wastewater could be the key challenges for practical application. In the future, more efforts should be made to develop novel cathodic catalysts that can allow the Fenton reaction under neutral conditions. The conductivity issue could be addressed by combining two different wastewaters of varying conductivity. 


\subsection{Implications}

This study demonstrated the applicability of continuous treatment of pharmaceuticals-contaminated wastewater using the scaled-up BEF process. Compared with the lab-scale BEF process, it has the following advantages:1) efficient treatment of high-load pharmaceuticals-contaminated wastewater;

2) lower operating costs for treating $1 \mathrm{~m}^{3}$ wastewater with the content of same pharmaceuticals (5.84 € vs. $71.25 €) ; 3)$ less addition of iron $(0.3 \mathrm{mM}$ vs. $7.5 \mathrm{mM})$. Though promising, several challenges still need to be addressed: 1) the need for $\mathrm{pH}$ adjustment before and after treatment; 2) iron sludge; 3) energy consumption mainly contributed by pumping and stirring.

To address the above challenges, more efforts should be made to develop novel catalysts that can enable the scaled-up BEF process under neutral conditions in the future. Furthermore, it is also possible to increase the gas-liquid mass transfer efficiency by designing the reactor configuration to further reduce the energy consumption of aeration.

\section{Conclusions}

This work presents that successfully designing and utilizing an innovative 20-L BEF system for continuously removing high concentration pharmaceuticals from wastewater. Six selected pharmaceuticals were completely removed with lower operating cost and followed by the pseudofirst-order kinetics. Moreover, a transformation pathway of clofibric acid was proposed according to the HPLC-MS/MS analysis of transformation products. Finally, the application in actual wastewater also exhibited good performance. The above results highlighted the feasibility of scaling-up BEF process as an efficient and cost-effective technology applied to pharmaceuticals containing wastewater treatment for future commercial application.

\section{Acknowledgments}

The authors would like to acknowledge the China Scholarship Council and the Novo Nordisk Foundation (NNF16OC0021568) for their financial support. In addition, Xiaohu Li is thanked for his contribution to parts of the experiments. 


\section{References}

Antonin, V.S., Santos, M.C., Garcia-Segura, S., Brillas, E., 2015. Electrochemical incineration of the antibiotic ciprofloxacin in sulfate medium and synthetic urine matrix. Water Res. 83, 3141. https://doi.org/10.1016/j.watres.2015.05.066

Bouissou-Schurtz, C., Houeto, P., Guerbet, M., Bachelot, M., Casellas, C., Mauclaire, A.-C., Panetier, P., Delval, C., Masset, D., 2014. Ecological risk assessment of the presence of pharmaceutical residues in a French national water survey. Regul. Toxicol. Pharmacol. 69, 296-303. https://doi.org/10.1016/j.yrtph.2014.04.006

Brillas, E., Sirés, I., Oturan, M.A., 2009. Electro-Fenton process and related electrochemical technologies based on Fenton's reaction chemistry. Chem. Rev. 109, 6570-6631. https://doi.org/10.1021/cr900136g

Chen, P., Wang, F., Zhang, Q., Su, Y., Shen, L., Yao, K., Chen, Z.-F., Liu, Y., Cai, Z., Lv, W., 2017. Photocatalytic degradation of clofibric acid by $g-\mathrm{C}_{3} \mathrm{~N}_{4} / \mathrm{P} 25$ composites under simulated sunlight irradiation: the significant effects of reactive species. Chemosphere 172, 193-200. https://doi.org/10.1016/j.chemosphere.2017.01.015

Estrada, A.L., Li, Y.-Y., Wang, A., 2012. Biodegradability enhancement of wastewater containing cefalexin by means of the electro-Fenton oxidation process. J. Hazard. Mater. 227, 41-48. https://doi.org/10.1016/j.jhazmat.2012.04.079

Fan, Y., Ai, Z., Zhang, L., 2010. Design of an electro-Fenton system with a novel sandwich film cathode for wastewater treatment. J. Hazard. Mater. 176, 678-684. https://doi.org/10.1016/j.jhazmat.2009.11.085

Feng, C.-H., Li, F.-B., Mai, H.-J., Li, X.-Z., 2010. Bio-electro-Fenton process driven by microbial fuel cell for wastewater treatment. Environ. Sci. Technol. 44, 1875-1880. https://doi.org/10.1021/es9032925 
Flox, C., Ammar, S., Arias, C., Brillas, E., Vargas-Zavala, A.V., Abdelhedi, R., 2006. ElectroFenton and photoelectro-Fenton degradation of indigo carmine in acidic aqueous medium. Appl. Catal. B Environ. 67, 93-104. https://doi.org/10.1016/j.apcatb.2006.04.020

Gurke, R., Rößler, M., Marx, C., Diamond, S., Schubert, S., Oertel, R., Fauler, J., 2015. Occurrence and removal of frequently prescribed pharmaceuticals and corresponding metabolites in wastewater of a sewage treatment plant. Sci. Total Environ. 532, 762-770. https://doi.org/10.1016/j.scitotenv.2015.06.067

Hassan, M., Pous, N., Xie, B., Colprim, J., Balaguer, M.D., Puig, S., 2017. Employing Microbial Electrochemical Technology-driven electro-Fenton oxidation for the removal of recalcitrant organics from sanitary landfill leachate. Bioresour. Technol. 243, 949-956. https://doi.org/10.1016/j.biortech.2017.07.042

Hey, G., Ledin, A., Jansen, J. la C., Andersen, H.R., 2012. Removal of pharmaceuticals in biologically treated wastewater by chlorine dioxide or peracetic acid. Environ. Technol. 33, 1041-1047. https://doi.org/10.1080/09593330.2011.606282

Hu, D., Li, X., Chen, Z., Cui, Y., Gu, F., Jia, F., Xiao, T., Su, H., Xu, J., Wang, H., 2018. Performance and extracellular polymers substance analysis of a pilot scale anaerobic membrane bioreactor for treating tetrahydrofuran pharmaceutical wastewater at different HRTs. J. Hazard. Mater. 342, 383-391. https://doi.org/10.1016/j.jhazmat.2017.08.028

Kahoush, M., Behary, N., Cayla, A., Nierstrasz, V., 2018. Bio-Fenton and Bio-electro-Fenton as sustainable methods for degrading organic pollutants in wastewater. Process Biochem. 64, 237-247. https://doi.org/10.1016/j.procbio.2017.10.003

Kvesitadze, G., Sadunishvili, T., Dudauri, T., Zakariashvili, N., Partskhaladze, G., Ugrekhelidze, V., Tsiklauri, G., Metreveli, B., Jobava, M., 2012. Two-stage anaerobic process for bio-hydrogen and bio-methane combined production from biodegradable solid wastes. Energy 37, 94-102. https://doi.org/10.1016/j.energy.2011.08.039 
Kümmerer, K., 2001. Drugs in the environment: emission of drugs, diagnostic aids and disinfectants into wastewater by hospitals in relation to other sources-a review. Chemosphere 45, 957-969. https://doi.org/10.1016/S0045-6535(01)00144-8

Labiadh, L., Oturan, M.A., Panizza, M., Hamadi, N. Ben, Ammar, S., 2015. Complete removal of AHPS synthetic dye from water using new electro-fenton oxidation catalyzed by natural pyrite as heterogeneous catalyst. J. Hazard. Mater. 297, 34-41. https://doi.org/10.1016/j.jhazmat.2015.04.062

Laurencé, C., Rivard, M., Martens, T., Morin, C., Buisson, D., Bourcier, S., Sablier, M., Oturan, M.A., 2014. Anticipating the fate and impact of organic environmental contaminants: a new approach applied to the pharmaceutical furosemide. Chemosphere 113, 193-199. https://doi.org/10.1016/j.chemosphere.2014.05.036

Li, W., Lu, S., Qiu, Z., Lin, K. 2010. Clofibric acid degradation in UV254/ $\mathrm{H}_{2} \mathrm{O}_{2}$ process: Effect of $\begin{array}{llll}\text { temperature. } & \text { J. } & \text { Hazard. } & \text { Mater. }\end{array}$ https://doi.org/10.1016/j.jhazmat.2009.11.147

Li, X., Jin, X., Zhao, N., Angelidaki, I., Zhang, Y., 2017a. Novel bio-electro-Fenton technology for azo dye wastewater treatment using microbial reverse-electrodialysis electrolysis cell. Bioresour. Technol. 228, 322-329. https://doi.org/10.1016/j.biortech.2016.12.114

Li, X., Jin, X., Zhao, N., Angelidaki, I., Zhang, Y., 2017b. Efficient treatment of aniline containing wastewater in bipolar membrane microbial electrolysis cell-Fenton system. Water Res. 119, 67-72. https://doi.org/10.1016/j.watres.2017.04.047

Li, X., Zhang, R., Qian, Y., Angelidaki, I., Zhang, Y., 2017c. The impact of anode acclimation strategy on microbial electrolysis cell treating hydrogen fermentation effluent. Bioresour. Technol. 236, 37-43. https://doi.org/10.1016/j.biortech.2017.03.160 
Liu, D., Zhang, H., Wei, Y., Liu, B., Lin, Y., Li, G., Zhang, F., 2018. Enhanced degradation of ibuprofen by heterogeneous electro-Fenton at circumneutral pH. Chemosphere 209, 998-1006. https://doi.org/10.1016/j.chemosphere.2018.06.164

Luo, Y., Guo, W., Ngo, H.H., Nghiem, L.D., Hai, F.I., Zhang, J., Liang, S., Wang, X.C., 2014. A review on the occurrence of micropollutants in the aquatic environment and their fate and removal during wastewater treatment. Sci. Total Environ. 473, 619-641. https://doi.org/10.1016/j.scitotenv.2013.12.065

Monteil, H., Péchaud, Y., Oturan, N., Oturan, M.A., 2019. A review on efficiency and cost effectiveness of electro-and bio-electro-Fenton processes: application to the treatment of pharmaceutical pollutants in water. Chem. Eng. J. 376, 119577. https://doi.org/10.1016/j.cej.2018.07.179

Moreira, F.C., Boaventura, R.A.R., Brillas, E., Vilar, V.J.P., 2017. Electrochemical advanced oxidation processes: a review on their application to synthetic and real wastewaters. Appl. Catal. B Environ. 202, 217-261. https://doi.org/10.1016/j.apcatb.2016.08.037

Nadais, H., Li, X., Alves, N., Couras, C., Andersen, H.R., Angelidaki, I., Zhang, Y., 2018. Bioelectro-Fenton process for the degradation of Non-Steroidal Anti-Inflammatory Drugs in wastewater. Chem. Eng. J. 338, 401-410. https://doi.org/10.1016/j.cej.2018.01.014

Olvera-Vargas, H., Oturan, N., Buisson, D., Oturan, M.A., 2016. A coupled bio-EF process for mineralization of the pharmaceuticals furosemide and ranitidine: feasibility assessment. Chemosphere 155, 606-613. https://doi.org/10.1016/j.chemosphere.2016.04.091

Oturan, M.A., Aaron, J.-J., 2014. Advanced oxidation processes in water/wastewater treatment: principles and applications. A review. Crit. Rev. Environ. Sci. Technol. 44, 2577-2641. https://doi.org/10.1080/10643389.2013.829765

Papageorgiou, M., Kosma, C., Lambropoulou, D., 2016. Seasonal occurrence, removal, mass loading and environmental risk assessment of 55 pharmaceuticals and personal care products 
in a municipal wastewater treatment plant in Central Greece. Sci. Total Environ. 543, 547-569. https://doi.org/10.1016/j.scitotenv.2015.11.047

Plakas, K. V, Sklari, S.D., Yiankakis, D.A., Sideropoulos, G.T., Zaspalis, V.T., Karabelas, A.J., 2016. Removal of organic micropollutants from drinking water by a novel electro-Fenton filter: pilot-scale studies. Water Res. 91, 183-194. https://doi.org/10.1016/j.watres.2016.01.013

Sirés, I., Arias, C., Cabot, P.L., Centellas, F., Garrido, J.A., Rodríguez, R.M., Brillas, E., 2007. Degradation of clofibric acid in acidic aqueous medium by electro-Fenton and photoelectroFenton. Chemosphere 66, 1660-1669. https://doi.org/10.1016/j.chemosphere.2006.07.039

Sirés, I., Brillas, E., Oturan, M.A., Rodrigo, M.A., Panizza, M., 2014. Electrochemical advanced oxidation processes: today and tomorrow. A review. Environ. Sci. Pollut. Res. 21, 8336-8367. https://doi.org/10.1007/s11356-014-2783-1

Tang, Y., Shi, X., Liu, Y., Feng, L., Zhang, L., 2018. Degradation of clofibric acid in UV/chlorine disinfection process: kinetics, reactive species contribution and pathways. R. Soc. open Sci. 5, 171372. https://doi.org/10.1098/rsos.171372

Thiam, A., Sirés, I., Brillas, E., 2015. Treatment of a mixture of food color additives (E122, E124 and E129) in different water matrices by UVA and solar photoelectro-Fenton. Water Res. 81, 178-187. https://doi.org/10.1016/j.watres.2015.05.057

Tran, N.H., Reinhard, M., Gin, K.Y.-H., 2018. Occurrence and fate of emerging contaminants in municipal wastewater treatment plants from different geographical regions-a review. Water Res. 133, 182-207. https://doi.org/10.1016/j.watres.2017.12.029

Vandenberg, L.N., Colborn, T., Hayes, T.B., Heindel, J.J., Jacobs Jr, D.R., Lee, D.-H., Shioda, T., Soto, A.M., vom Saal, F.S., Welshons, W. V, 2012. Hormones and endocrine-disrupting chemicals: low-dose effects and nonmonotonic dose responses. Endocr. Rev. 33, 378-455. https://doi.org/10.1210/er.2011-1050 
Wahab, H.S., Bredow, T., Aliwi, S.M., 2009. A computational study on the adsorption and ring cleavage of para-chlorophenol on anatase $\mathrm{TiO}_{2}$ surface. Surf. Sci. 603, 664-669. https://doi.org/10.1016/j.susc.2009.01.001

Wang, F., Wu, Y., Gao, Y., Li, H., Chen, Z., 2016. Effect of humic acid, oxalate and phosphate on Fenton-like oxidation of microcystin-LR by nanoscale zero-valent iron. Sep. Purif. Technol. 170, 337-343. https://doi.org/10.1016/j.seppur.2016.06.046

Wang, W., Lu, Y., Luo, H., Liu, G., Zhang, R., Jin, S., 2018. A microbial electro-fenton cell for removing carbamazepine in wastewater with electricity output. Water Res. 139, 58-65. https://doi.org/10.1016/j.watres.2018.03.066

Wilkinson, J.L., Hooda, P.S., Barker, J., Barton, S., Swinden, J., 2016. Ecotoxic pharmaceuticals, personal care products, and other emerging contaminants: A review of environmental, receptor-mediated, developmental, and epigenetic toxicity with discussion of proposed toxicity to humans. Crit. Rev. Environ. Sci. Technol. 46, 336-381. https://doi.org/10.1080/10643389.2015.1096876

Xu, N., Zeng, Y., Li, J., Zhang, Y., Sun, W., 2015. Removal of 17ß-estrodial in a bio-electroFenton system: contribution of oxidation and generation of hydroxyl radicals with the Fenton reaction and carbon felt cathode. RSC Adv. 5, 56832-56840. https://doiorg.proxy.findit.dtu.dk/10.1039/C5RA08053C

Xu, N., Zhang, Y., Tao, H., Zhou, S., Zeng, Y., 2013. Bio-electro-Fenton system for enhanced estrogens degradation. Bioresour. Technol. 138, 136-140. https://doi.org/10.1016/j.biortech.2013.03.157Get rights and content

Yong, X.-Y., Gu, D.-Y., Wu, Y.-D., Yan, Z.-Y., Zhou, J., Wu, X.-Y., Wei, P., Jia, H.-H., Zheng, T., Yong, Y.-C., 2017. Bio-Electron-Fenton (BEF) process driven by microbial fuel cells for triphenyltin chloride (TPTC) degradation. J. Hazard. Mater. 324, 178-183. https://doi.org/10.1016/j.jhazmat.2016.10.047 
Zhang, H., Choi, H.J., Huang, C.-P., 2006. Treatment of landfill leachate by Fenton's reagent in a continuous stirred tank reactor. J. Hazard. Mater. 136, 618-623. https://doi.org/10.1016/j.jhazmat.2005.12.040

Zhang, H., Ran, X., Wu, X., 2012. Electro-Fenton treatment of mature landfill leachate in a continuous flow reactor. J. Hazard. Mater. 241, 259-266. https://doi.org/10.1016/j.jhazmat.2012.09.040

Zhang, L., Yin, X., Li, S.F.Y., 2015. Bio-electrochemical degradation of paracetamol in a microbial fuel cell-Fenton system. Chem. Eng. J. 276, 185-192. https://doi.org/10.1016/j.cej.2015.04.065

Zhang, X., Liu, Z., Kong, Q., Liu, G., Lv, W., Li, F., Lin, X., 2018. Aquatic photodegradation of clofibric acid under simulated sunlight irradiation: kinetics and mechanism analysis. RSC Adv. 8, 27796-27804. https://doi.org/10.1039/C8RA03140A

Zhang, Y., Angelidaki, I., 2015. Recovery of ammonia and sulfate from waste streams and bioenergy production via bipolar bioelectrodialysis. Water Res. 85, 177-184. https://doi.org/10.1016/j.watres.2015.08.032

Zhang, Y., Wang, Y., Angelidaki, I., 2015. Alternate switching between microbial fuel cell and microbial electrolysis cell operation as a new method to control $\mathrm{H}_{2} \mathrm{O}_{2}$ level in BioelectroFenton system. J. Power Sources 108-116. https://doi.org/10.1016/j.jpowsour.2015.05.020

Zhao, X., Qu, J., Liu, H., Qiang, Z., Liu, R. and Hu, C. 2009. Photoelectrochemical degradation of anti-inflammatory pharmaceuticals at $\mathrm{Bi}_{2} \mathrm{MoO}_{6}$-boron-doped diamond hybrid electrode under visible light irradiation. Appl. Catal. B Environ. 91(1-2), 539-545 https://doi.org/10.1016/j.apcatb.2009.06.025

Zhou, M., Oturan, M.A., Sires, I., 2018. Electro-Fenton Process. Springer. https://doi.org/10.1007/978-981-10-6406-7 
Zhu, X., Ni, J., 2009. Simultaneous processes of electricity generation and p-nitrophenol degradation in a microbial fuel cell. Electrochem. commun. 11, 274-277. https://doi.org/10.1016/j.elecom.2008.11.023

Zupanc, M., Kosjek, T., Petkovšek, M., Dular, M., Kompare, B., Širok, B., Blažeka, Ž., Heath, E. 2013. Removal of pharmaceuticals from wastewater by biological processes, hydrodynamic cavitation and UV treatment. Ultrason. sonochem. 20 (4), 1104-1112. https://doi.org/10.1016/j.ultsonch.2012.12.003 


\section{Figure captions}

Fig. 1. Schematic of BEF system structure and operation. (a) Picture of 20-L BEF system. a, Synthetic nutrient medium feed in the anode chamber; b, Effluent from the anode chamber; c, Anode chamber; d, Cathode chamber; e, Synthetic pharmaceutical wastewater feed in the cathode chamber (Pharmaceuticals: carbamazepine, clofibric acid, ketoprofen, naproxen, diclofenac, ibuprofen); f, Effluent in the cathode chamber (treated pharmaceutical wastewater). (b) Graphical configuration of the electrode arrangement. (c) Flow chart of 20-L BEF system under operation condition.

Fig. 2. System performance on the degradation of six selected pharmaceuticals. Control 1, open circuit; Control 2, without air flow in the cathode; Control 3, without $\mathrm{Fe}^{2+}$ addition. BEF operational conditions: initial concentration of each pharmaceutical was $500 \mu \mathrm{g} \mathrm{L}^{-1}$, initial $\mathrm{pH}$ of 3 , $\mathrm{Fe}^{2+}$ of $1 \mathrm{mM}, \mathrm{Na}_{2} \mathrm{SO}_{4}$ of $50 \mathrm{mM}$, applied voltage of $0.2 \mathrm{~V}$ (for the control experiment) and air flow rate of $350 \mathrm{~mL} \mathrm{~min}^{-1}$.

Fig. 3. The effect of applied voltage on system performance. BEF operational conditions: initial concentration each pharmaceutical was $500 \mu \mathrm{g} \mathrm{L}-1$, initial $\mathrm{pH}$ of $2.8, \mathrm{Fe}^{2+}$ of $1 \mathrm{mM}, \mathrm{Na}_{2} \mathrm{SO}_{4}$ of 50 $\mathrm{mM}, \mathrm{HRT}$ of $23 \mathrm{~h}$, and air flow rate of $350 \mathrm{~mL} \mathrm{~min}^{-1}$.

Fig. 4. The effect of the initial concentration of six selected pharmaceuticals on system performance. BEF operational conditions: initial $\mathrm{pH}$ of $2.8, \mathrm{Fe}^{2+}$ of $1 \mathrm{mM}, \mathrm{Na}_{2} \mathrm{SO}_{4}$ of $50 \mathrm{mM}$, HRT of $23 \mathrm{~h}$, and air flow rate of $350 \mathrm{~mL} \mathrm{~min}^{-1}$.

Fig.5. The effect of HRT on system performance. BEF operational conditions: initial concentration each pharmaceutical was $500 \mu \mathrm{g} \mathrm{L}^{-1}$, initial $\mathrm{pH}$ of $2.8, \mathrm{Fe}^{2+}$ of $1 \mathrm{mM}, \mathrm{Na}_{2} \mathrm{SO}_{4}$ of $50 \mathrm{mM}$, and air flow rate of $350 \mathrm{~mL} \mathrm{~min}^{-1}$. 
Fig.6. The effect of initial $\mathrm{Fe}^{2+}$ concentration on system performance. BEF operational conditions: initial concentration of each pharmaceutical was $500 \mu \mathrm{g} \mathrm{L}^{-1}$, initial $\mathrm{pH}$ of 2.8 , applied voltage of 0.1 $\mathrm{V}, \mathrm{Na}_{2} \mathrm{SO}_{4}$ of $50 \mathrm{mM}, \mathrm{HRT}$ of $26 \mathrm{~h}$, and air flow rate of $350 \mathrm{~mL} \mathrm{~min}^{-1}$.

Fig.7. Proposed clofibric acid transformation pathway during this 20-L BEF system.

Fig.8. The effect of the water matrix on the degradation of six selected pharmaceuticals by this $20-\mathrm{L}$ BEF system. BEF operational conditions: initial concentration of each pharmaceutical was $500 \mu \mathrm{g}$ $\mathrm{L}^{-1}$, initial $\mathrm{pH}$ of 2.8 , applied voltage of $0.1 \mathrm{~V}$ and $0.2 \mathrm{~V}$, HRT of $26 \mathrm{~h}$ and $36 \mathrm{~h}$, and air flow rate of $350 \mathrm{~mL} \mathrm{~min}^{-1}$. 
Table 1. Summary of studies on the BEF process degradation of pharmaceuticals

\begin{tabular}{|c|c|c|c|c|c|c|c|}
\hline Pollu & ants & $\begin{array}{l}\text { Reactor } \\
\text { design }\end{array}$ & $\begin{array}{c}\text { BEF } \\
\text { system } \\
\text { volume }\end{array}$ & $\begin{array}{l}\text { Optimized } \\
\text { operational } \\
\text { parameters }\end{array}$ & $\begin{array}{l}\text { Removal } \\
\text { rate }\end{array}$ & $\begin{array}{l}\text { Operati } \\
\text { on } \\
\text { mode }\end{array}$ & $\begin{array}{c}\text { Referen } \\
\text { ce }\end{array}$ \\
\hline NSAIDs & $\begin{array}{c}\text { Ketoprofen } \\
\text { Diclofenac } \\
\text { Ibuprofen } \\
\text { Naproxen }\end{array}$ & $\begin{array}{l}\text { Two } \\
\text { chambe } \\
\text { rs }\end{array}$ & $\begin{array}{l}\text { The total } \\
\text { volume of } \\
\text { each } \\
\text { chamber } \\
\text { was } 100 \\
\mathrm{~mL}(80 \\
\mathrm{mL} \text { of } \\
\text { working } \\
\text { volume) }\end{array}$ & $\begin{array}{l}\text { Initial } \\
\text { concentrati } \\
\text { on of } 40 \mu \mathrm{g} \\
\mathrm{L}^{-1} \text { for each } \\
\text { compound, } \\
\mathrm{Fe}^{2+} \text { of } 7.5 \\
\mathrm{mM}, \mathrm{pH} \text { of } \\
2 \text {, applied } \\
\text { voltage of } \\
0.3 \mathrm{~V} \text { and } \\
\text { air flow } \\
\text { rate of } 8 \\
\mathrm{~mL} \mathrm{~min}^{-1}\end{array}$ & $\begin{array}{l}59-61 \% \\
\text { removal } \\
\text { of } \\
\text { ketoprofe } \\
\mathrm{n}, 87- \\
97 \% \\
\text { removal } \\
\text { of } \\
\text { diclofena } \\
\text { c, } 80- \\
86 \% \\
\text { removal } \\
\text { of } \\
\text { ibuprofen } \\
\text { and } 75- \\
81 \% \\
\text { removal } \\
\text { of } \\
\text { naproxen } \\
\text { in } 5 \text { h }\end{array}$ & Batch & $\begin{array}{l}\text { (Nadais } \\
\text { et al., } \\
\text { 2018) }\end{array}$ \\
\hline $\begin{array}{c}\text { Anticonvulsa } \\
\text { nts }\end{array}$ & $\begin{array}{l}\text { Carbamazepi } \\
\text { ne }\end{array}$ & $\begin{array}{l}\text { Single } \\
\text { chambe } \\
\mathrm{r}\end{array}$ & $28 \mathrm{~mL}$ & $\begin{array}{l}\text { Initial } \\
\text { concentrati } \\
\text { on of } 10 \\
\mathrm{mg} \mathrm{L}^{-1} \text {, } \\
\mathrm{Na}_{2} \mathrm{SO}_{4} \text { of } \\
5 \mathrm{~g} \mathrm{~L}^{-1} \text { and } \\
0.18 \mathrm{~g} \mathrm{~L}^{-1} \\
\text { of Fe-Mn } \\
\text { binary } \\
\text { oxide as a } \\
\text { catalyst } \\
\text { coated on } \\
\text { the surface } \\
\text { of the } \\
\text { cathode }\end{array}$ & $\begin{array}{l}90 \% \\
\text { removal } \\
\text { in } 24 \mathrm{~h} .\end{array}$ & Batch & $\begin{array}{l}\text { (Wang } \\
\text { et al., } \\
2018)\end{array}$ \\
\hline $\begin{array}{l}\text { Prescription } \\
\text { and OTC } \\
\text { medication }\end{array}$ & Paracetamol & $\begin{array}{l}\text { Two } \\
\text { chambe } \\
\text { rs }\end{array}$ & $\begin{array}{l}\text { The } \\
\text { working } \\
\text { volume of } \\
\text { cathode } \\
\text { and anode } \\
\text { chamber } \\
\text { were } \\
216 \mathrm{~mL} \\
\text { and } \\
108 \mathrm{~mL} \text {, }\end{array}$ & $\begin{array}{l}\text { Initial } \\
\text { concentrati } \\
\text { on of } 10 \\
\mathrm{mg} \mathrm{L}^{-1}, \\
\mathrm{Fe}^{2+} \text { of } 5 \\
\mathrm{mg} \mathrm{L}^{-1}, \mathrm{pH} \\
\text { of } 2, \\
\text { external } \\
\text { resistance } \\
\text { of } 20 \Omega\end{array}$ & $\begin{array}{l}70 \% \\
\text { removal } \\
\text { in } 9 \mathrm{~h}\end{array}$ & Batch & $\begin{array}{l}\text { (Zhang } \\
\text { et al., } \\
2015 a)\end{array}$ \\
\hline
\end{tabular}




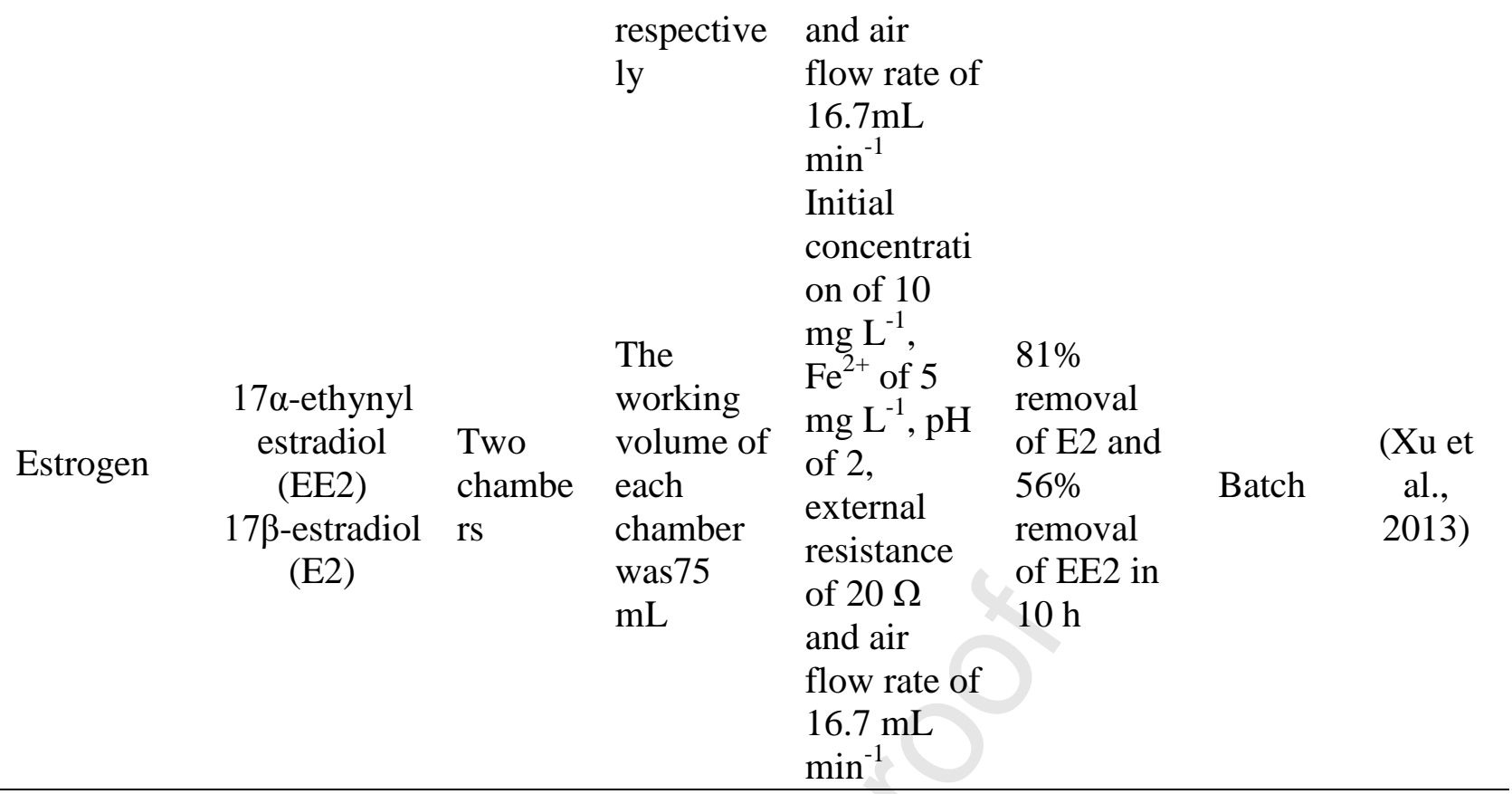

Table 1. (Continued)

\begin{tabular}{|c|c|c|c|c|c|c|c|}
\hline \multicolumn{2}{|c|}{ Pollutants } & \multicolumn{2}{|c|}{$\begin{array}{cc}\begin{array}{c}\text { Reactor } \\
\text { design }\end{array} & \text { BEF } \\
& \text { system } \\
& \text { volum } \\
& \mathrm{e} \\
\end{array}$} & $\begin{array}{l}\text { Optimized } \\
\text { operational } \\
\text { parameters }\end{array}$ & $\begin{array}{l}\text { Remov } \\
\text { al rate }\end{array}$ & $\begin{array}{c}\text { Operatio } \\
\mathrm{n} \\
\text { mode }\end{array}$ & $\begin{array}{l}\text { Referen } \\
\text { ce }\end{array}$ \\
\hline Estrogen & $\begin{array}{c}\text { 17ß-estradiol } \\
\text { (E2) }\end{array}$ & $\begin{array}{l}\text { Two } \\
\text { chambe } \\
\text { rs }\end{array}$ & $\begin{array}{l}\text { The } \\
\text { workin } \\
\text { g } \\
\text { volum } \\
\text { e of } \\
\text { each } \\
\text { chamb } \\
\text { er } \\
\text { was } 75 \\
\text { mL }\end{array}$ & $\begin{array}{c}\text { Initial } \\
\text { concentrati } \\
\text { on of } 0.12 \\
\mathrm{mg} \mathrm{L}^{-1}, \mathrm{pH} \\
\text { of } 3, \\
\text { external } \\
\text { resistance } \\
\text { of } 150 \Omega \\
\text { and } \mathrm{NaCl} \\
\text { of } 0.1 \mathrm{M}\end{array}$ & $\begin{array}{l}90 \% \\
\text { remova } \\
1 \text { in } 6 \mathrm{~h}\end{array}$ & Batch & $\begin{array}{l}\text { (Xu et } \\
\text { al., } \\
2015)\end{array}$ \\
\hline $\begin{array}{l}\text { Emerging } \\
\text { contaminants }\end{array}$ & $\begin{array}{c}\text { Bisphenol } \\
\text { A(BPA) } \\
\text { Estrone (E1) } \\
\text { Sulfamethazine } \\
\text { (SM2) } \\
\text { Triclocarban(T } \\
\text { CC) }\end{array}$ & $\begin{array}{c}\text { Two } \\
\text { chambe } \\
\text { rs }\end{array}$ & $\begin{array}{l}\text { The } \\
\text { total } \\
\text { volum } \\
\text { e of } \\
\text { each } \\
\text { chamb } \\
\text { er was } \\
120 \\
\text { mL (64 } \\
\text { mL of }\end{array}$ & $\begin{array}{c}\text { Initial } \\
\text { concentrati } \\
\text { on of } 1 \mathrm{mg} \\
\mathrm{L}^{-1} \text { for each } \\
\text { compound, } \\
\mathrm{Fe}^{2+} \text { of } \\
1.25 \mathrm{mM}, \\
\mathrm{pH} \text { of } 3, \\
\text { and } \\
\mathrm{Na}_{2} \mathrm{SO}_{4} \text { of } \\
0.1 \mathrm{M}\end{array}$ & $\begin{array}{l}100 \% \\
\text { of E1 } \\
\text { and } \\
\text { SM2, } \\
99 \% \text { of } \\
\text { TCC, } \\
\text { and } \\
75 \% \\
\text { BPA in } \\
24 \mathrm{~h}\end{array}$ & Batch & $\begin{array}{l}\text { (Wang } \\
\text { et al., } \\
2017 \text { ) }\end{array}$ \\
\hline
\end{tabular}




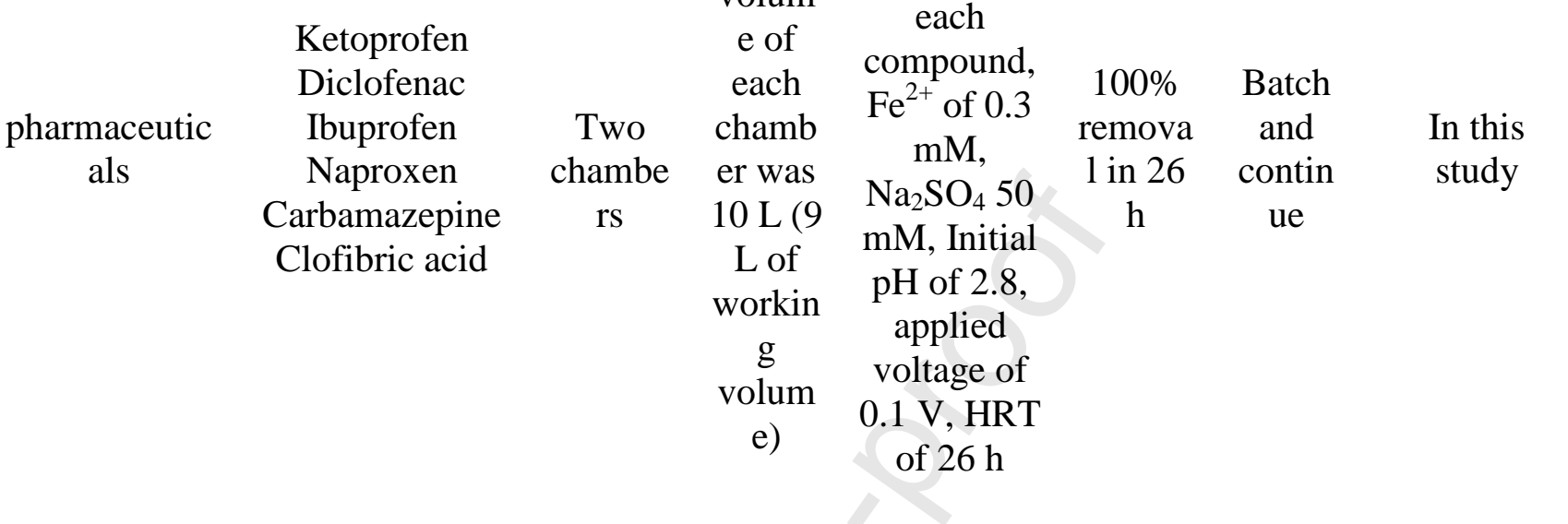

workin

$\mathrm{g}$

volum

e)

Initial

concentrati

The on of 500

total $\mu \mathrm{g} \mathrm{L}^{-1}$ for

each

chamb

er was

L of

$\mathrm{mM}$, Initial

$\mathrm{pH}$ of 2.8

applied

ltage of

of $26 \mathrm{~h}$ 


\section{CRediT authorship contribution statement}

Rusen Zou: Methodology, Validation, Formal analysis, Writing - original draft. Irini Angelidaki: Resources,

Supervision, Validation, Funding acquisition. Xiaoyong Yang: Investigation, Visualization. Kai Tang:

Investigation, Visualization. Henrik Rasmus Andersen: Resources, Validation. Yifeng Zhang:

Conceptualization, Resources, Supervision, Funding acquisition. 


\section{Declaration of competing interest}

The authors declare that they have no known competing financial interests or personal relationships that could have appeared to influence the work reported in this paper. 
Graphical abstract

\section{Highlights}

- A 20-L BEF reactor was built for continuous pharmaceuticals wastewater treatment.

- Pharmaceuticals were completely removed with low energy consumption.

- The key operational parameters were investigated in 20-L BEF process.

- Two transformation pathways and six transformation products were identified.

- Successfully applied in continuous removal of pharmaceuticals in real wastewater. 
a)

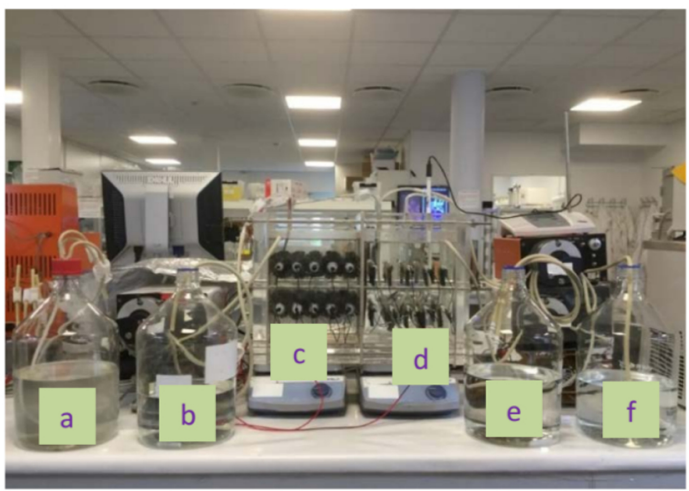

b)
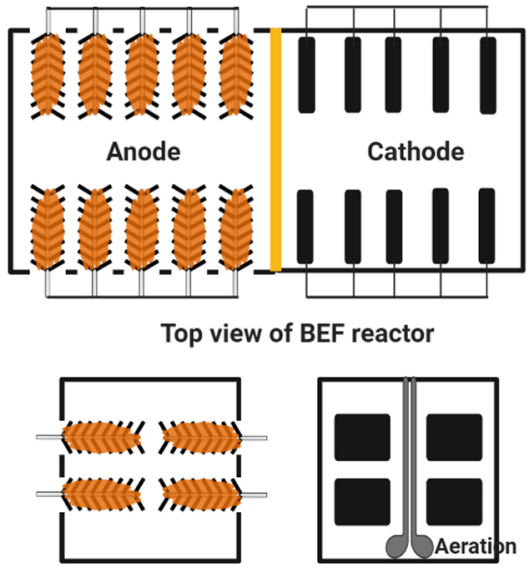

Side view of BEF reactor

c)

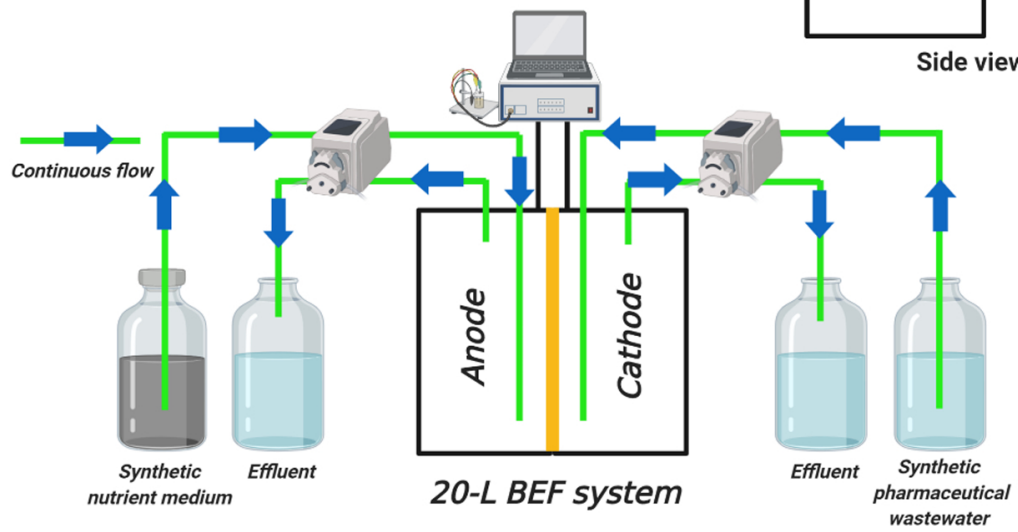

Figure 1 

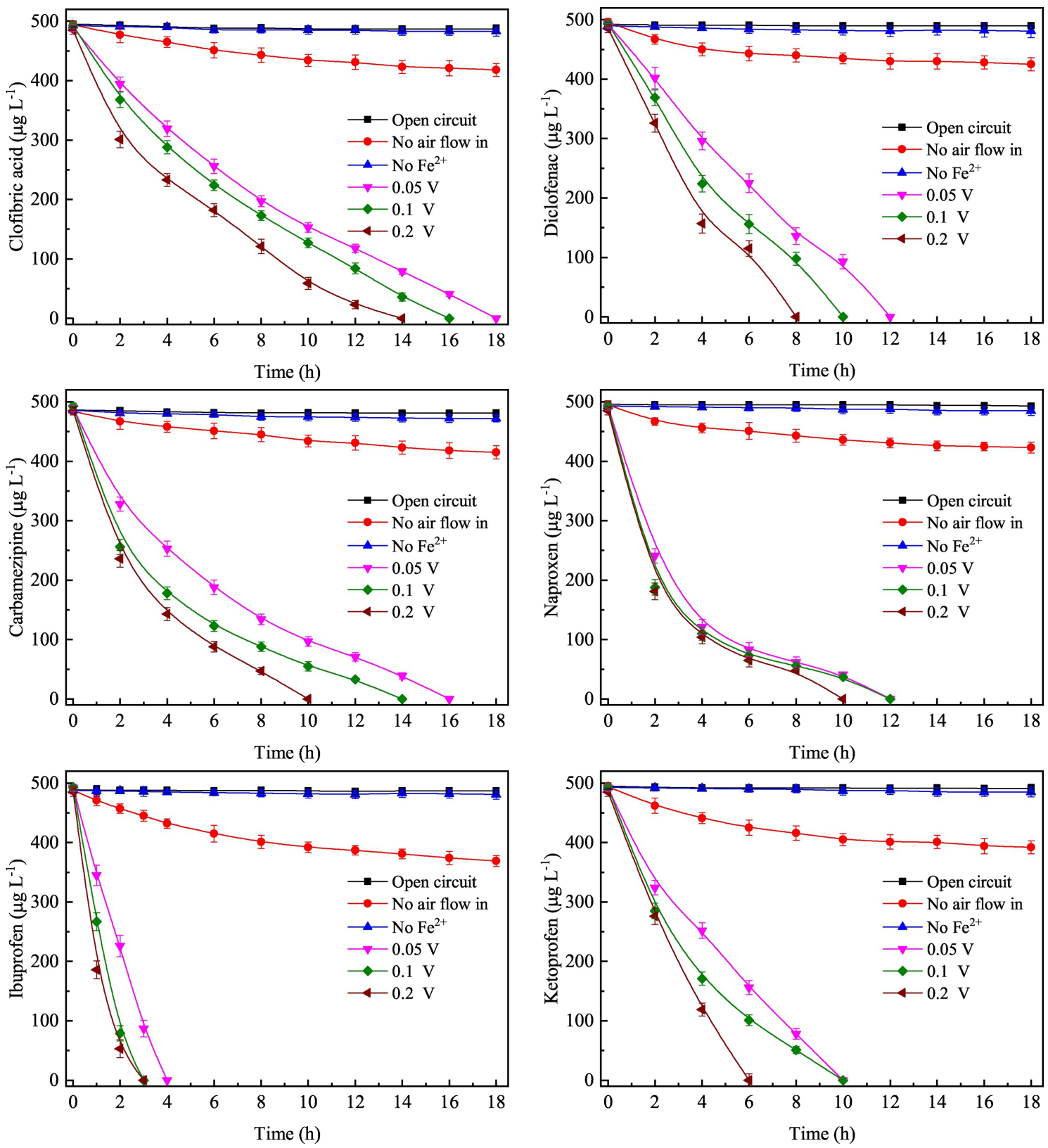

Figure 2 

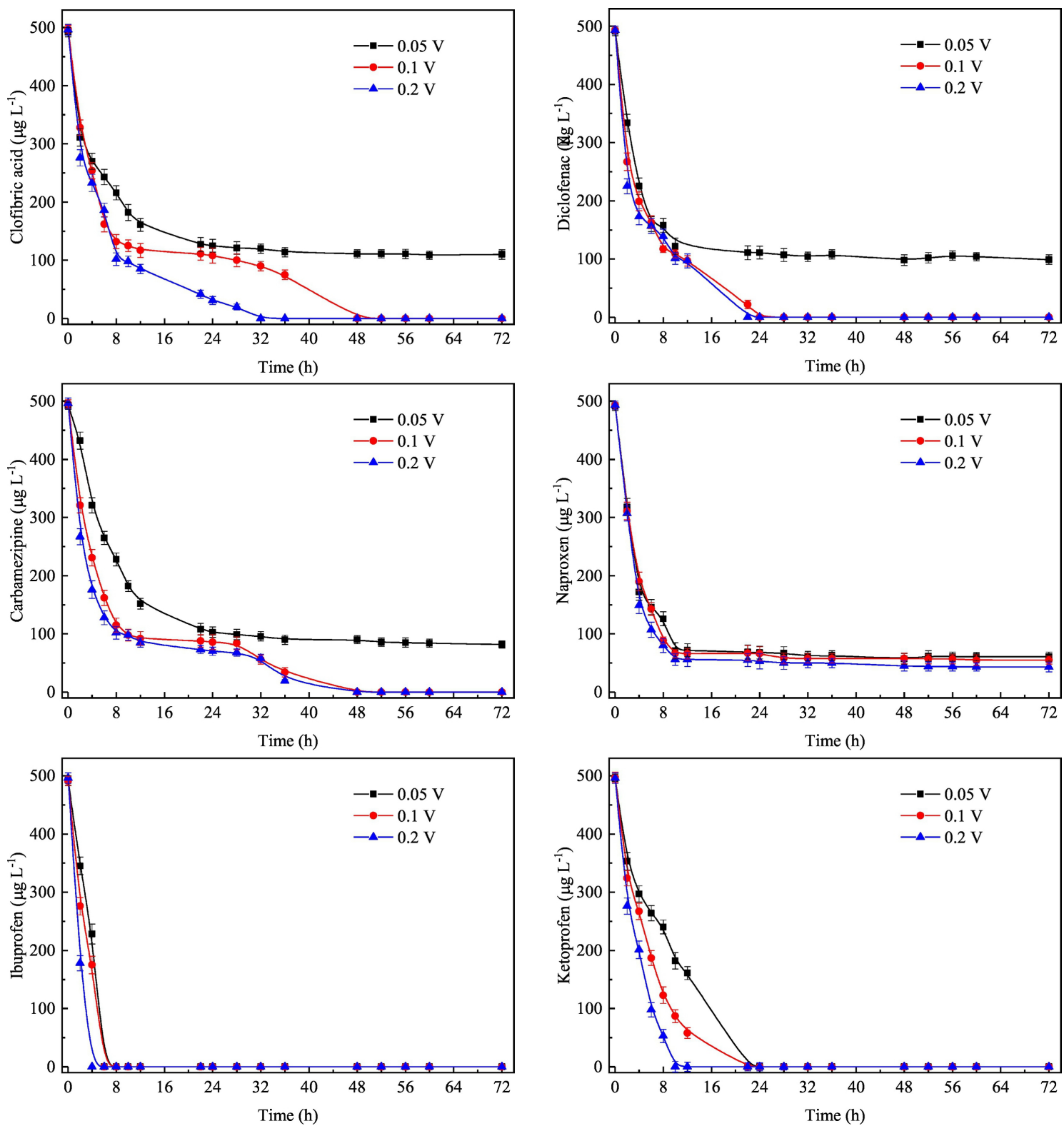

Figure 3 

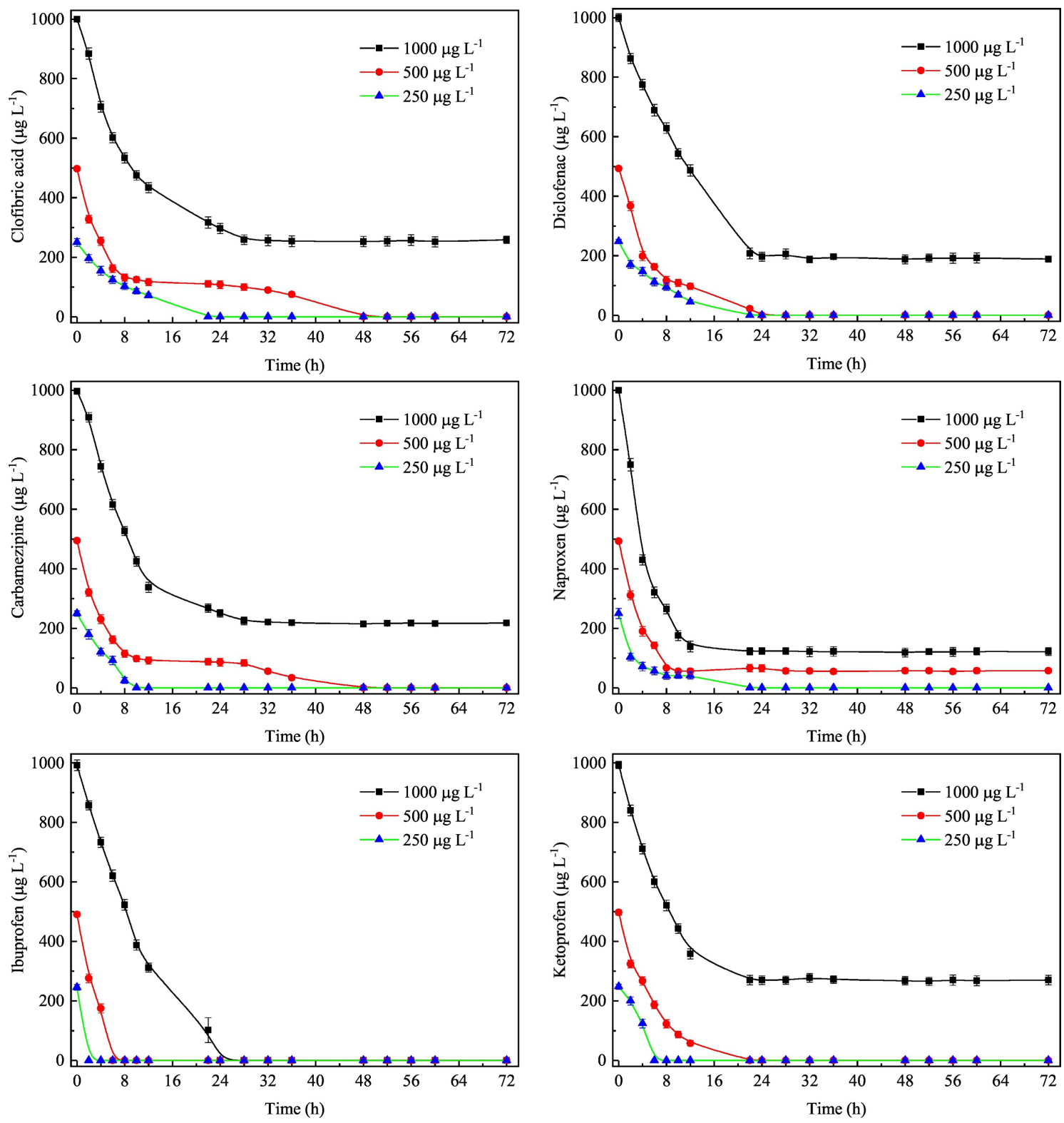

Figure 4 

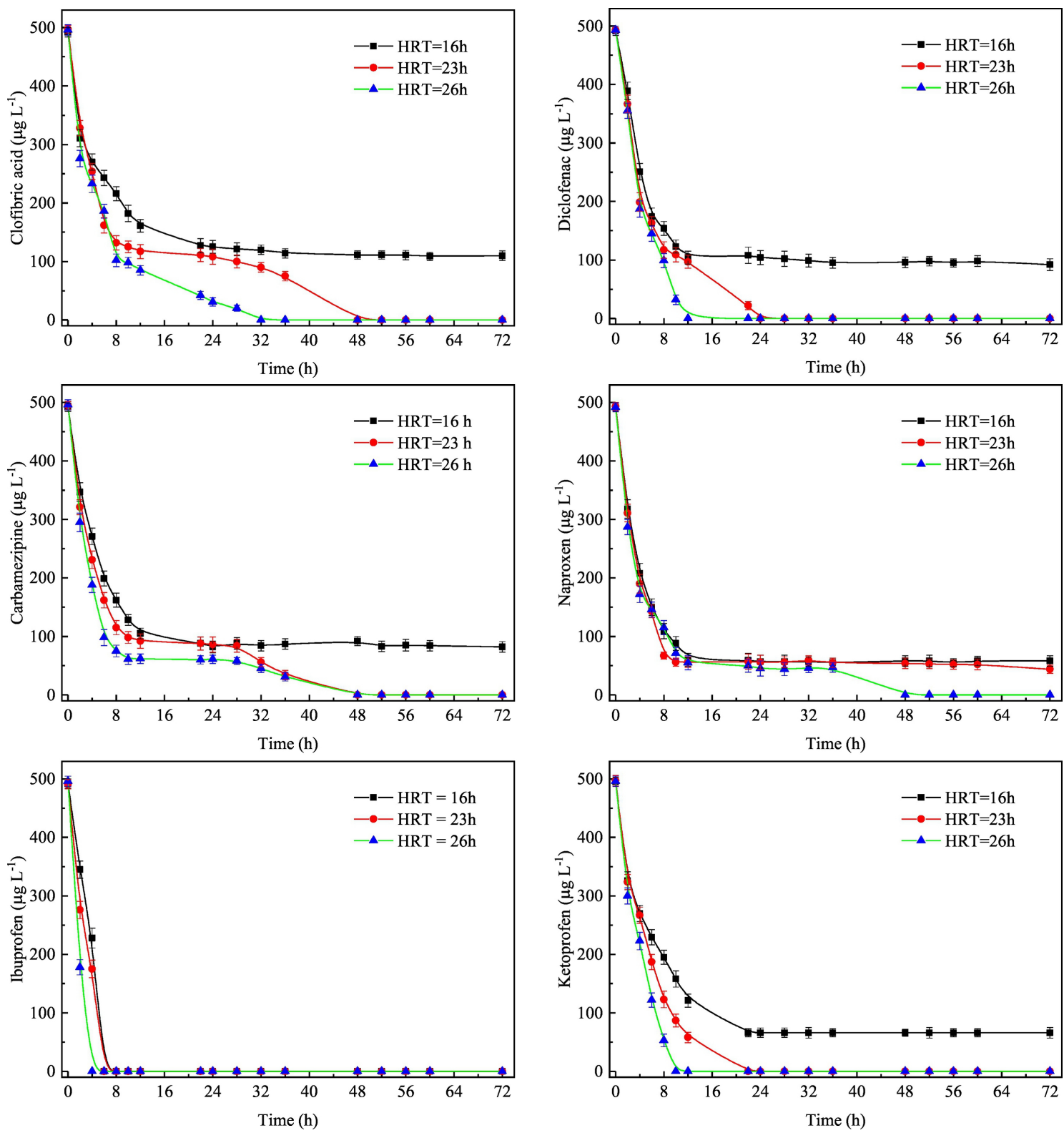

Figure 5 

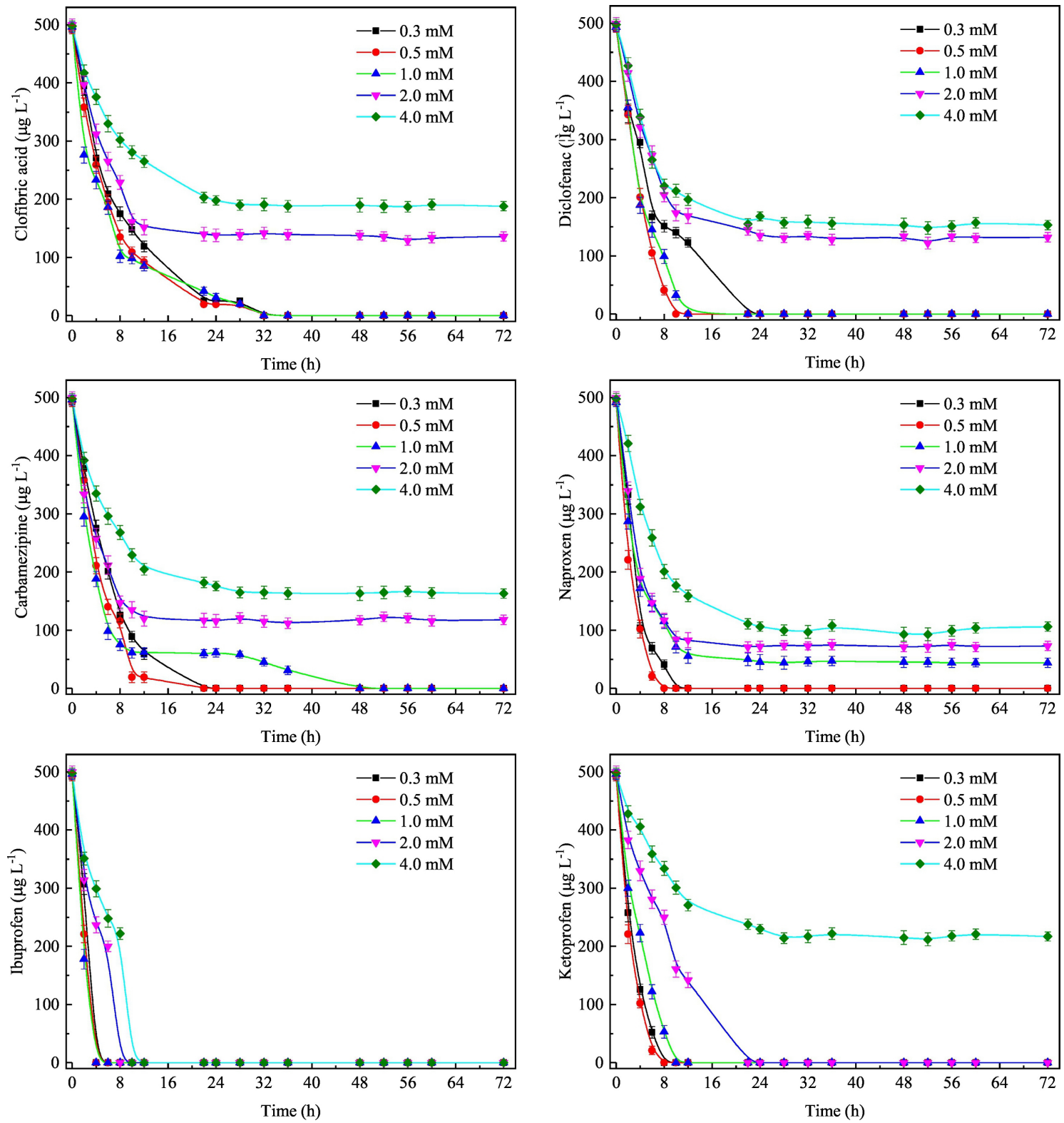

Figure 6 


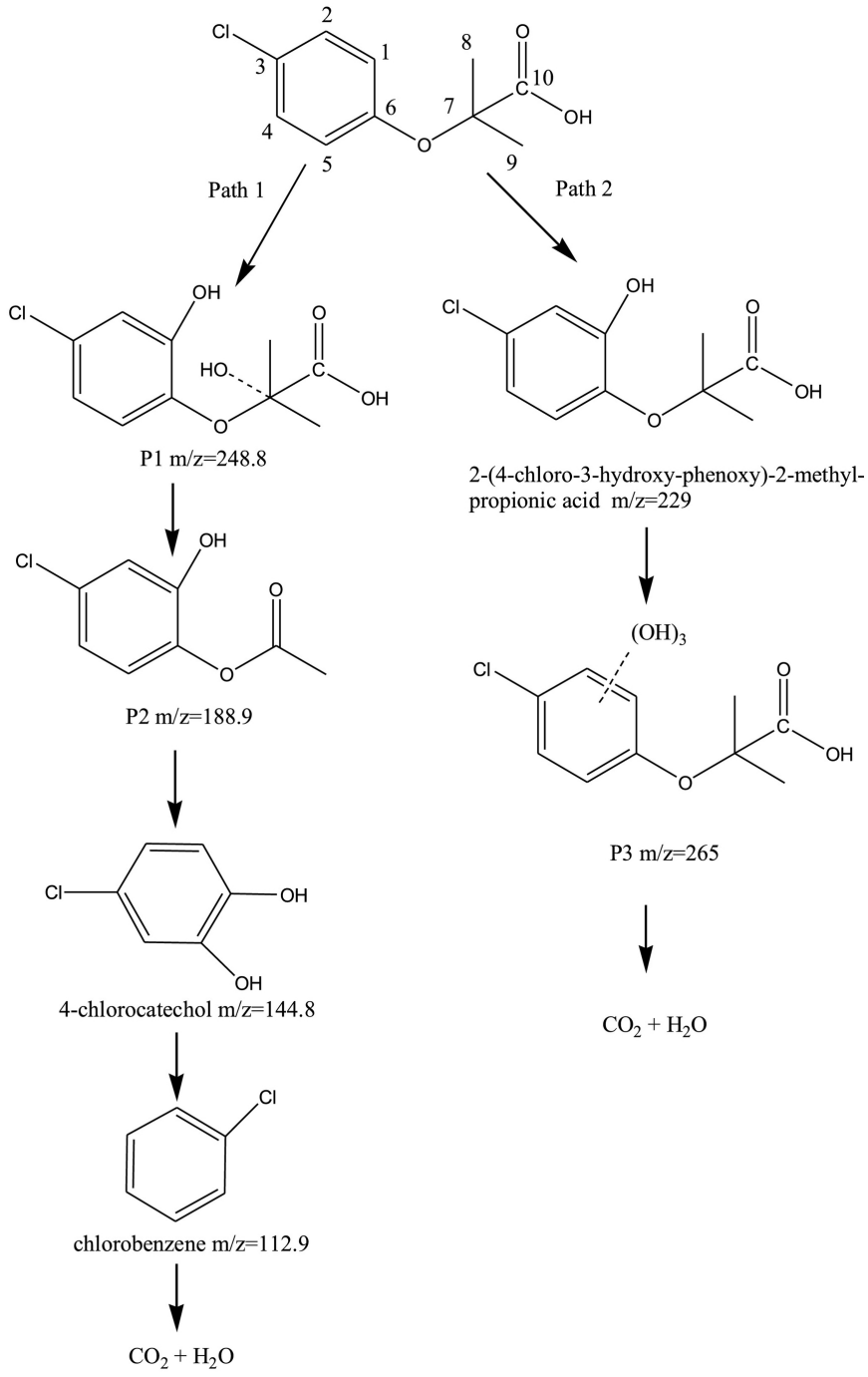




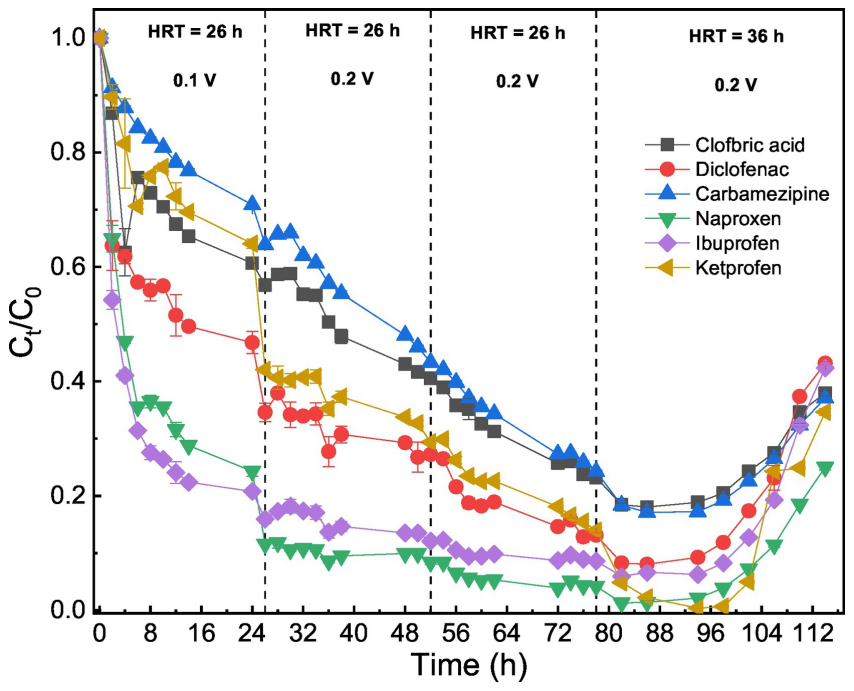

Figure 8 